\title{
Hodnocení rizika vysychání drobných vodních toků v České republice
}

\section{SVĚTLANA ZAHRÁDKOVÁ, ONDŘEJ HÁJEK, PAVEL TREML, PETR PAŘIL, MICHAL STRAKA, DENISA NĚMEJCOVÁ, MAREK POLÁŠEK, PAVEL ONDRÁČEK}

\author{
Klíčová slova: sucho - mapa - tok - deficit srážek - krajinný pokryv - makrozoobentos - bioindikace
}

\section{SOUHRN}

Pro Českou republiku byla navržena kategorizace území z hlediska rizika vysychání drobných vodních toků (I. až IV. rád podle Strahlera). Byly stanoveny tři stupně rizika (malé, střední a velké) pro detailní plošky povodí (povodí IV. rádu). Stupně rizika byly definovány na základě hodnot vybraných abiotických charakteristik povodí a jejich kombinací. Výběr charakteristik a jejich hraniční hodnoty byly odvozeny metodou klasifikačních stromů. Klasifikovány byly lokality, které byly rozděleny do skupin podle toho, zda na nich bylo zjištěno vysychání. Vysychání bylo detekováno metodou retrospektivní biologické indikace. Tato nová metoda, založená na analýze makrozoobentosu, byla vyvinuta na základě komplexního výzkumu vysychajících i permanentních toků v období 2012-2015. Pomocí uvedené metody bylo vyhodnoceno 332 lokalit (1362 vzorků), sledovaných na drobných vodních tocích ČR v rozmezí let 1997 až 2015. Výsledný stupeň rizika vysychání drobných vodních toků pro vytvoření mapy byl odvozen pomocí metody klasifikačních stromů z deficitu srážek, typu krajinného pokryvu, podílu hornin s obsahem jílovců, parametrů geomorfologických a z podílu stojatých vod v povodí. Území s malým rizikem vysychání představuje $45,3 \%$, se středním 23,3 \% a s velkým rizikem 31,3 \% rozlohy ČR. Vysoce riziková jsou povodí s převahou orné půdy a podílem vodních ploch větším než $1 \%$. Kategorizace má sloužit jako podklad pro rozhodovací procesy zejména pro management vodního hospodářství, zemědělství a ochrany prírody.

\section{ÚVOD}

Sucho je fenomén, který je obtížné jednoznačně definovat, přestože je mu věnována značná pozornost i mimo oblasti s typicky aridním klimatem. Dopady sucha se v posledních letech zabývá i řada projektů ve střední Evropě. Na problematiku sucha Ize nahližet z různých hledisek, komplexní pohled s akcentem na ekologické aspekty v akvatických systémech nabízí v mezinárodním měřítku monografie Drought and aquatic ecosystems [1]. Sucho v českých zemích je všestranně vyhodnoceno $v$ aktuálně vydané monografii zpracované týmem odborníků pod vedením profesorů Brázdila a Trnky [2]. Česká republika nebyla $v$ minulosti považována za zemi bezprostředně ohroženou suchem, ačkoliv se období sucha s nezanedbatelnými důsledky vyskytovala i v minulosti [2-6]. Situace se změnila na přelomu tisíciletí, zejména po extrémním průběhu počasí v roce 2003 [7] a také v roce 2015, kdy byla např. na řadě toků zaznamenána historická minima za období celého přístrojového sledování [8]. Fenomén sucha se tak dostal do popředí zájmu řady resortů státní správy, zejména Ministerstva zemědělství a Ministerstva životního prostředí. Oba resorty byly na základě Usnesení k prípravě realizace opatření pro zmírnění negativních dopadů sucha a nedostatku vody vládou ČR pověřeny zpracovat během dvou let koncepci ochrany před následky sucha [9].

Pro tvorbu koncepce budou důležitými vstupy jak identifikace př́čin výskytu sucha, tak kategorizace území z hlediska míry rizika výskytu sucha, protože do oblastí s vysokým rizikem by měla být směřována jednotlivá opatření k omezení následků sucha. Zásadním vstupem by také měla být znalost účinnosti jednotlivých typů opatření.

K vymezení rizikových území lze přistupovat různě podle toho, zda je sledováno sucho meteorologické, hydrologické, zemědělské nebo socioekonomické. Základním prístupem pro toto vymezení je využívání indexů sucha různého typu; přehled a hodnocení jejich predností a slabin viz [2, 10]. Často jsou používány indexy založené na meteorologických datech, např. v evropském měřítku byla navržena klasifikace území na úrovni kombinovaných územních celků NUTS (Nomenclature of Units for Territorial Statistics), založená na využití indexu SPEI (Standardized Precipitation Evapotranspiation Index) [11]. V ČR jsou z pohledu sucha meteorologická data také intenzivně analyzována (viz www.chmi.cz a [8]). Kategorizace území na základě hodnocení pomocí několika klimatických indexů je uvedena v Atlasu podnebí Česka [12]. Hodnocením sucha zemědělského $s$ důrazem na jeho krátkodobou predikci se intenzivně věnuje Ústav agrosystémů a bioklimatologie na Mendelově univerzitě v Brně (www.intersucho.cz). Identifikaci zranitelných oblastí z hlediska nedostatku vodních zdrojů pro současnost i budoucí období provedli např. Beran a Hanel [13], početné další prístupy k hodnocení rizik spojených se suchem jsou uvedeny $v$ monografii o suchu [2].

Jedním z nejnápadnějších projevů epizod sucha je pokles hladin vodních toků. Toto tzv. hydrologické sucho je intenzivně studováno na základě hodnocení údajů z hydrologických stanic, které jsou obvykle umístěny na větších tocích. Sucho je pro tento účel definováno určitou hranicí zabezpečeného průtoku (zpravidla hranice Q95, ale např. i $Q_{355}$ apod.). Velmi nízké průtoky, a zejména průtoky nulové, mají závažné dopady na přežití živých organismů (bioty) s konsekvencemi nejen pro jakost vod, ale i pro jednotlivé ekosystémy $v$ krajině, pro které je voda jedním z předpokladů samotné existence. Problematice nízkých, nulových a takzvaně minimálně prípustných průtoků byla věnována pozornost již v minulosti, v ČR viz např. práce M. Zelinky [14]. V období implementace směrnice 2000/60/ES (Rámcová směrnice o vodách) [15] je akcentována problematika ekologického stavu vodních útvarů povrchových vod a díky tomu jsou koncepty optimálního stanovení minimálních zůstatkových prưtoků dále rozvíjeny. Kategorizaci území České republiky do čtyř typů oblastí v závislosti na charakteru hydrologického režimu a na klíčových procesech, které se v dané oblasti podílejí na tvorbě odtoku, navrhli Mrkvičková a Balvín v souvislosti s návrhem postupu stanovení minimálních zůstatkových průtoků [16]. 
Z hlediska typu toků, na kterých dochází v obdobích sucha k nejmarkantnějším změnám, patří k nejohroženějším toky menší, I. až IV. rádu podle Strahlera [17]. Jejich hydrologický režim více závisí na lokálních podmínkách v konkrétním malém povodí, než je tomu u toků větších. Na většině malých toků zpravidla nejsou umístěny měřicí stanice a exaktní údaje o jejich průtocích chybí. K výskytu nízkých průtoků až k vyschnutí toků však objektivně dochází, to Ize doložit údaji z informačního systému (IS) SALAMANDER (www.is2ms.monsms.cz) bývalé Zemědělské vodohospodářské správy (ZVHS), v němž jsou uložena data z monitoringu drobných vodních toků. Informace o vyschnutí pochází také z terénních průzkumů autorů.

Pojmem vyschnutí toku je v kontextu této publikace míněno úplné vymizení povrchového průtoku z koryta toku (mohou zbývat pouze izolované tůně bez propojení s povrchovým tokem). Tento jev, zejména pokud nastane na delším úseku toku po delší dobu (dny až měsíce), má dalekosáhlé dopady na ekologický stav toku i chemické vlastnosti vody. Dalším významným negativním důsledkem vyschnutí toku je narušení jeho funkce jako významného krajinného prvku, nebot toky slouží jako biokoridory. To pak vede ke zvýšení fragmentace rríční sítě a degradaci jejích funkcí v krajině.

Průtoky ve větších tocích jsou i v podmínkách kulturní krajiny do značné míry závislé na vodnosti toků nižších řádů. Posuzujeme-li říční sít v ČR podle délky toků, pak podíl toků I. až IV. řádu činí téměř $92 \%$. Jejich stav do značné míry odráží stav krajiny jako celku. Znalost konkrétní míry rizika vyschnutí menších toků je dưležitá přinejmenším pro management vodního hospodářství, zemědělství a ochrany prírody.

Výzkumem vysychání drobných vodních toků, jeho důsledky pro vodní biotu a možnostmi zpětné (retrospektivní) indikace epizody vyschnutí toku bioindikačními metodami se zabývá tým pracovníků Výzkumného ústavu vodohospodárského T. G. Masaryka, v.v.i., Mendelovy univerzity a firmy WELL Consulting, s. r. O., v projektu podporovaném Technologickou agenturou ČR: Vysychání toků v období klimatické změny: predikce rizika a biologická indikace epizod vyschnutí jako nové metody pro management vodního hospodářství a údržby krajiny (projekt č. TA02020395, akronym BIOSUCHO).

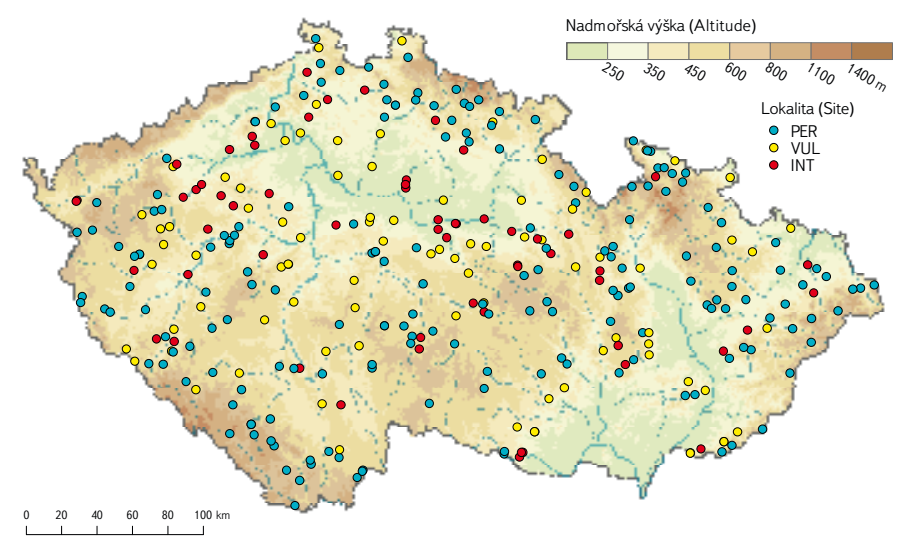

Obr. 1. Rozmístění lokalit na malých vodních tocích klasifikovaných metodou retrospektivní bioindikace do tříd podle permanence průtoku: PER - toky stále tekoucí, VUL toky vysychající nepravidelně, INT - toky vysychající pravidelně

Fig. 1. The distribution of sites used in the analyses, classified by the retrospective bioindication method into groups according to the permanence of flow: PER (permanent) - a constant flow, VUL (vulnerable) - an irregular drying up, INT (intermittent) - a regular drying up
Retrospektivní indikace vysychání toků je založena na analýzách makrozoobentosu. Makrozoobentos, čili makroskopičtí bezobratlí živočichové obývající dno vodních biotopů, citlivě reagují na epizody vyschnutí toku. Dochází ke kvalitativním i kvantitativním změnám ve struktuře společenstev, které jsou identifikovatelné při hodnocení standardně odebíraných vzorků makrozoobentosu, a to po dobu nejméně jednoho roku po vyschnutí. Uvedenou metodou byly vyhodnoceny vzorky makrozoobentosu nejen z projektu BIOSUCHO, ale i vhodné vzorky uložené v databázi IS SALAMANDER, vytvořeného v letech 1997 až 2010.

Jedním z cílů projektu BIOSUCHO je také vymezení oblastí, v nichž je zvýšené riziko vysychání drobných vodních toků (DVT). V tomto príspěvku se proto zabýváme kategorizací území ČR podle míry rizika vysychání drobných vodních toků. Kategorizace je provedena na základě abiotických charakteristik povodí, zpracovatelných do vrstev GIS, a výsledků hodnocení makrozoobentosu z obou uvedených zdrojů.

Průtoky v tocích obecně jsou ovlivňovány řadou faktorů se synergickým nebo antagonistickým účinkem. Jedná se o jevy klimatické, které jsou v čase proměnlivé a člověkem minimálně ovlivnitelné, o převážně stabilní charakteristiky geologické a geomorfologické, o složitě hydrogeologicky podmíněné poměry v podzemních vodách a v neposlední řadě o vlivy lidské činnosti, které je možné korigovat (odběry povrchových a podzemních vod, manipulace s průtoky, údržba krajiny, renaturace či revitalizace toků).

Vstupní výběr abiotických charakteristik pro tuto studii byl proveden podle výsledků předchozích výzkumů. Z literárních údajů byla převzata informace o tom, že povodí na jílovcích vykazují signifikantně vyšší hodnoty nedostatkových objemů než povodí s jinou litologií [18]. V rámci vlastních předběžných analýz v projektu BIOSUCHO bylo provedeno podrobné hydrogeologické posouzení situace na 87 úsecích toků (lokalitách), z nichž 32 bylo vysychavých a 55 nevysychavých [19]. Jako nejvýznamnějši důvod vysychání byl uveden odběr podzemní vody v povodí, zvětšení mocnosti kvartérních náplavových uloženin spojené se změnou spádu toku a výskyt rádově propustnějších vložek hornin v povodí. Jako potenciálně riziková byla na základě této studie hodnocena povodí drobných toků, kterými procházejí hranice mezi geomorfologickými podcelky s poklesem střední výšky terénu větším než $200 \mathrm{~m}$ a/nebo změnou sklonu svahů. Pro některé

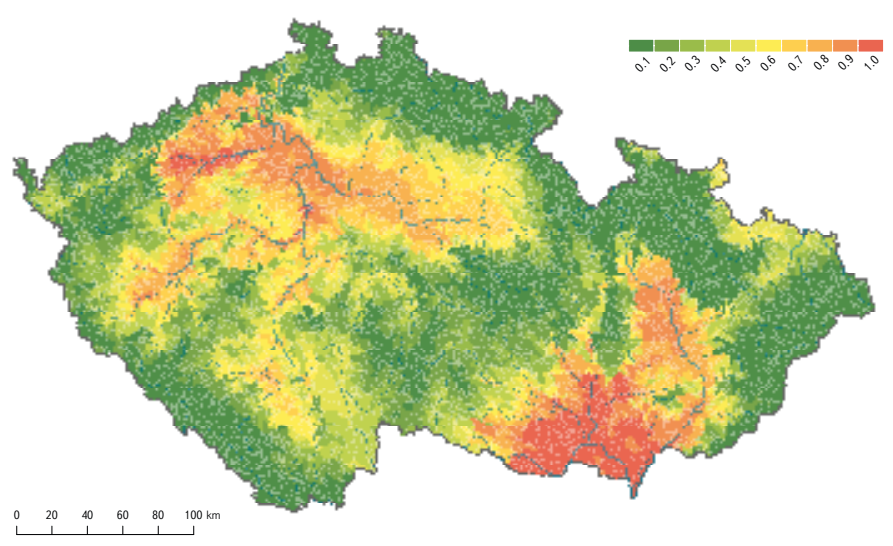

Obr. 2. Mapa deficitu srážek: kvantily rozdílů úhrnů srážek a evapotranspirace pro povodí IV. rádu; hodnota 0,1 odpovídá situaci, kdy evapontraspirace převládá nad srážkami v povodí v 0-10 \% případů, tedy jen v nejsušších letech; hodnota 1 odpovídá situaci, kdy evapontraspirace převládá nad srážkami v povodí v 91-100 \% prípadů Fig. 2. Map of the rainfall deficit: quantiles of the differences between precipitation and evapotranspiration in the $4^{\text {th }}$ order catchments (the smallest hydrological units); the value 0.1 corresponds to a situation when evapotranspiration prevails over precipitation in the catchment in $0-10 \%$ of cases, i.e. in the driest years; the value 1 corresponds to a situation when evapotranspiration prevails over precipitation in the catchment in $91-100 \%$ of cases 
z uvedených charakteristik však bylo problematické získat kompletní a konzistentní údaje pro vrstvy GIS v přiměřené podrobnosti. Pro další hodnocení byla proto jako použitelná dále zpracována charakteristika výskytu významných tektonických linií a vyhodnocen podíl krasových a pseudokrasových jevů jako určitý zástupný ukazatel k propustnosti podloží v povodí. Hranice mezi geomorfologickými jednotkami byly dále zpracovány podrobněji - na úrovni okrsků (viz Metodiku).

Z antropogenních vlivů byl jako dále využitelný vyhodnocen ukazatel typu krajinného pokryvu. Vliv různých typů povrchů na toky z hlediska kvalitativního i kvantitativního byl prokázán [20]. Na průtoky v tocích mají objektivně vliv také nádrže různého typu v jejich povodí, proto byl zařazen také podíl ploch stojatých vod v hodnoceném povodí.

Výstižnost klasifikace území, tedy i výběr jednotlivých mapových vrstev a poté jejich kombinací, byla posuzována pomocí informací o reálném vyschnutí toků (pozorování anebo měření v terénu) a podle výsledků hodnocení biologických vzorků nově vyvinutou metodou retrospektivní indikace vyschnutí toku podle makrozoobentosu [21].

Cílem studie tedy byla kategorizace území ČR z hlediska rizika vysychání drobných vodních toků v podobě mapy v měřítku 1 : 200000. Dílčími cíli bylo: (i) posouzení významnosti abiotických charakteristik územních jednotek na úrovni povodí IV. řádu z hlediska rizika vysychání drobných vodních toků, a to na základě informací získaných prímými (pozorování, měření) i nepř́mými (retrospektivní bioindikace) metodami a (ii) konstrukce mapy rizika na základě kombinace vybraných vrstev, tj. kategorizace území. Kategorizace území bude od r. 2016 k dispozici v portálu Hydroekologického informačního systému HEIS (www.heisvuv.cz).

\section{METODIKA}

\section{Zdroje dat}

Za drobné vodní toky pro účel této studie považujeme toky od I. do IV. řádu podle Strahlera. Rámcově se toto vymezení shoduje s pojetím drobných vodních toků, které byly v gesci bývalé ZVHS. Data použitá pro konstrukci map Ize rozdělit na informace o živé složce - makrozoobentosu (data biotická) a na informace o abiotických charakteristikách. Vzorky makrozoobentosu, odebírané pomocí ruční sítě v jarní a podzimní sezoně semikvantitativní metodou PERLA [22], pocházely ze sledování modelových lokalit v projektu BIOSUCHO (celkem 23 lokalit, sledované období 2012-2014, celkový počet vzorků 110). Dalším zdrojem dat byla databáze IS SALAMANDER, která obsahuje údaje o odběrech makrozoobentosu na 900 lokalitách, a to jak antropogenně ovlivněných, tak v prírodě blízkém stavu, na kterých bylo provedeno téměř 5000 odběrů. Data z tohoto zdroje byla pro analýzy, jejichž výsledky jsou prezentované v tomto článku, očištěna od údajủ z lokalit vykazujících známky organického znečištění (hodnoceno přednostně podle hodnot saprobního indexu, rutinně užívané bioindikační metody [23]) s ohledem na velikost toku na hranici oligo- a beta-mezosaprobity, resp. středu beta-mezosaprobity. Dále byly vyřazeny lokality, na nichž byly zjištěny nízké hodnoty pH (s výskytem minimálních hodnot $<6$, nebo mediánových hodnot $<7$ ). Vzorky makrozoobentosu z takto ovlivněných lokalit mohou vykazovat změny podobné těm, které jsou vyvolány vysycháním, a to by vedlo k chybným výsledkưm prováděných analýz. Do dalšího hodnocení byly zařazeny lokality sledované nejméně jeden rok v jarním a podzimním aspektu v případě minimálně antropogenně ovlivněných toků, což byly lokality systému PERLA, tzv. referenční [24], které byly téměř výlučně nevysychající. V př́ipadě dat z takzvaného standardního monitoringu ZVHS, mezi nimiž byly ponechány i toky s ovlivněným hydrologickým režimem nebo s úpravami koryt, byly hodnoceny lokality sledované minimálně dva roky. Z uvedených zdrojů pocházela také část dat abiotických, vztahujících se k lokalitám a vzorkům, další údaje pocházely z vrstev geografických informačních systémů (GIS), jejichž původ je popsán níže.

\section{Klasifikace lokalit}

Jednotlivé vzorky byly vyhodnoceny metodou rektrospektivní bioindikace [21] do tři tríd:

— INT - intermitentní (intermittent) - vysychající rádově na týdny na úseku toku delším než $1 \mathrm{~km}$;

— VUL - zranitelné (vulnerable) - vysychající nepravidelně, rádově na stovkách metrů pouze na několik dní;

- PER - permanentní (permanent) - trvale tekoucí.

Hodnocení vzorků na základě analýzy makrozoobentosu podle uvedené metodiky bylo převedeno na klasifikaci lokalit následujícím způsobem: jako INT byla vyhodnocena lokalita v prípadě dvou a více vzorků makrozoobentosu hodnocených jako INT, nebo jednoho vzorku INT a jednoho či více vzorků hodnocených jako VUL. Jako VUL byla lokalita hodnocena v prípadě výskytu nejméně dvou vzorků hodnocených jako VUL, výjimečně také při kombinaci vzorků PER a jednoho vzorku INT. $V$ prípadě poměru výsledků VUL : PER $=1: 3$ a vyšším ve prospěch PER byla lokalita hodnocena jako PER. Pokud nebylo možné vzorek odebrat z důvodu vyschnutí, byla daná sezona hodnocena jako INT.

\section{KATEGORIZACE ÚZEMÍ}

\section{Územní jednotky pro hodnocení}

Kategorizace území byla provedena na úrovni hydrologického povodí IV. rádu, tedy detailních plošek povodí (http://www.dibavod.cz/data/text_charakteristiky_toku.pdf). Pokud je v textu použit pojem „povodí" bez dalšího upřesnění (povodí Odry, povodí nad lokalitou apod.), jsou vždy míněna povodí IV. řádu. Vyšší úrovní pro hodnocení byly útvary povrchových vod (http://heis.vuv.cz/data/spusteni/identchk.asp?typ=96 \& oblast=isvs_utv),tj.významné územní celky pro vodohospodářský management, které je možné agregovat do dalších vyšších jednotek.

\section{Vrstvy GIS testované pro konstrukci mapy rizika vysychání drobných vodních toků}

Na základě výsledků předběžných výzkumů bylo pro hodnocení pripraveno sedm níže uvedených vrstev GIS. První z nich je mapa deficitu srážek, která vymezuje oblasti, v nichž převládá výpar nad srážkami. Mapa byla konstruována na základě dat ze 131 bodů pravidelné čtvercové sítě o velikosti gridu $25 \times 25 \mathrm{~km}$. Pro výpočet byly použity časové řady teplot vzduchu a úhrnů srážek z období let 1961-2011 (které poskytl Český hydrometeorologický ústav data byla odvozena $v$ rámci projektu s názvem Zpresnění dosavadních odhadů dopadů klimatické změny $v$ sektorech vodního hospodářství, zemědělství a lesnictví a návrhy adaptačních opatření [25] (metodika odvození gridových dat je popsána v Štěpánkovi a kol. [26], chybějící novější data pak dopočítána). Z časových řad teplot vzduchu byla pro každý den vypočtena evapotranspirace podle vztahu Oudina [27]. Z časových řad evapotranspirace a srážek byl pro každý bod gridové sítě $25 \times 25$ km stanoven deficit srážek (úhrn srážek, který chybí v daném bodě k rovnováze mezi výparem a srážkami) podle vzorce:

$$
R_{d}=E P_{d}-S R A_{d}
$$

kde $R_{d}$ je rozdíl mezi vypočtenými hodnotami evapotranspirace a úhrnů srážek za jeden den $v \mathrm{~mm}, \mathrm{EP}_{\mathrm{d}}$ je vypočtená hodnota evapotranspirace pro konkrétní 
den a SRA $A_{d}$ je denní úhrn srážek $v$ mm. Pro každý gridový bod byly z rozdílu úhrnů srážek a evapotranspirace vypočteny kvantily rozdílů úhrnů srážek a evapotranspirace po $10 \%$. Pro tyto kvantily byly pomocí plošné interpolace (užívající interpolační metody IDW a digitálního modelu reliéfu) vytvořeny mapy znázorňující oblasti, v nichž u daného kvantilu převládá evapotranspirace nad srážkami.

Hodnoty kvantilư byly převedeny do škály $0-1$, přičemž 0 znamená minimální rizikovost z hlediska vysychání DVT.

Jako dalši vhodné vrstvy pro doplnění klimatického modelu deficitu srážek byly pro tvorbu výsledné mapy rizika vysychání DVT vybrány nebo vytvořeny de novo níže uvedené vrstvy pro GIS a převedeny na škálu o rozsahu 0-1.

\section{VRSTVY PŘíRODNÍCH PODMÍNEK}

- Výskyt hornin s obsahem jílovců v povodí (http://www.geology.cz/extranet/mapy) ( 0 = žádné jílovce v podloží, 1 = 100 \% jílovců v podloží).

— Výskyt významných hranic mezi geomorfologickými okrsky [28] v povodí. Postup odvození: linie je hranice mezi geomorfologickými okrsky $X$ a $Y$; absolutní hodnota rozdílu průměrné nadmořské výšky $X$ a průměrné nadmořské výšky $Y$ dělená stem je koeficient nadmořské výšky; absolutní hodnota rozdílu průměrného sklonu svahu $X$ a průměrného sklonu svahu $Y$ dělená dvěma je koeficient sklonu svahu; součtem těchto dvou koeficientů je dán celkový koeficient výšky a sklonu pro každou hraniční linii. Každému povodí je prriřazena hodnota vypočtená jako délka všech linií (hranic mezi geomorfologickými okrsky) procházejících povodím, přičemž délka každé linie byla vynásobena svým koeficientem. Převod na škálu 0-1 byl odvozen od maximální hodnoty zjištěné pro ČR.

- Výskyt oblasti krasů a pseudokrasů, podchycující oblasti s krasovým typem propustnosti, a tedy specifickým hydrologickým režimem; mapa byla založena na informacích AOPK (http://jeso.nature.cz/) [29], (0 = žádné krasy či pseudokrasy, 1 = $100 \%$ plochy povodí tvořeno krasy nebo pseudokrasy).

- Výskyt významných tektonických jevů - poruch, zlomů v povodí (http: //www.geology.cz/extranet/mapy) byl hodnocen pro jednotlivá povodí IV. rádu podle geologické mapy GeoČR 500 tak, že bylo individuálně posuzováno, zda jde o jev, který mưže mít zřetelný vliv na vodní režim toku, nebo tento vliv není pravděpodobný (např. krátký zlom ležící v okrajové části povodí nebyl dále zvažován), výsledkem je binární hodnocení (0/1).

\section{VRSTVY ANTROPOGENNÍCH VLIVU゚}

— Typ krajinného pokryvu (landuse): jednotky definované podle manuálu (http: //www.eea.europa.eu/publications/tech40add) byly expertně spojeny do tří skupin z hlediska jejich očekávaného vlivu na průtoky hodnocených toků Hodnocen byl podíl typu 2 ( 0 = absence v povodí, $1=100 \%$ v povodí) s ohledem na minoritní podíl typu 1 a z toho plynoucí komplementarity typů 0 a 2:
- typ 0 - žádný nebo nepatrný negativní vliv: třída 4 (humidní území), část třídy 3 - 3.1, 3.2, 321, 322, 324, tj. převážně lesy a křoviny);

- typ 1 - mírně negativní nebo nevyhraněný typ - části tríd 2 (2.2, 2.3, 221, 222, 231, 241, 243 a 3.3 mimo výše uvedené v typu 0);

- typ 2 - zřetelně negativní vliv (třída 1 - urbanizovaná území, část trídy 2 - orná půda (2.1) a komplexní systémy kultur a parcel (242).

- Podíl plochy stojatých vod v povodí: hodnoceno na základě dat z databáze DIBAVOD [30] (www.dibavod.cz). Vyloučeny byly všechny nádrže označené jako vodní nádrže (v. n.) se základním objemem větším než 2000000 m³ (což je jeden z důležitých parametrů pro definici tzv. malé vodní nádrže podle ČSN 752410 [31]), z vodních nádrží pod tímto limitem pak byly vyloučeny i další, pokud neměly účel rybochovný, rekreační anebo závlahový. Nádrže označené jako rybník byly vždy ponechány. Cílem bylo, aby ukazatel v maximální možné miře postihoval vliv rybníkü, resp. malých vodních nádrží. Hodnota $0=$ povodí bez hodnocených nádrží, 0,001 = 0,1 \% plochy povodí tvoří stojaté vody; tedy v povodí o 100 km² se nachází 10 hektarů vodních ploch.

Pro většinu lokalit (314) bylo možno na základě údajů z terénních protokolů, fotografické dokumentace a mapových podkladů odvodit zjednodušené hodnocení míry ovlivnění morfologie toku. Tato charakteristika byla použita pro doplňkové hodnocení, protože není zpracovatelná v podobě vrstvy GIS. Byly stanoveny tři typy:

- typ 0 - žádné nebo nepatrné negativní ovlivnění (přirozené koryto i břeh, nanejvýše staré směrové úpravy a fixace břehů stromy);

- typ 1 - středně negativní ovlivnění (naprímené toky, obvykle s pomístně opevněnými břehy, s břehovými porosty stromů a keřů);

- typ 2 - zřetelné negativní ovlivnění (naprímené toky s opevněnými břehy a často i dnem, bez souvislých břehových porostů.

\section{Výběr a kategorizace abiotických charakteristik území pro konstrukci mapy rizika vysychání}

Byly vybírány abiotické charakteristiky povodí podchytitelné ve vrstvách GIS, jejichž kombinace nejlépe rozlišovaly územní jednotky z hlediska výskytu lokalit typu PER, VUL a INT a na jejichž základě Ize území ČR klasifikovat podle rizika vysychání drobných vodních toků do tři kategorií: riziko malé (R_0), střední (R_1) a velké (R_2).

Výběr charakteristik a identifikace jejich hraničních hodnot pro jednotlivé úrovně dělení byl proveden pomocí metody klasifikačních stromů v programu Statistica for Windows 12 [32]. Do analýzy vstupovalo sedm výše uvedených

Tabulka 1. Základni charakteristiky 332 lokalit použitých pro analýzy vedouci ke kategorizaci územi ČR z hlediska rizika vysycháni drobných vodních toků Table 1. The basic characteristics of the 332 sites that were used in the analyses resulting in the categorization of the area of the Czech Republic in terms of the risk of drying up of small streams

\begin{tabular}{|c|c|c|c|c|c|c|c|c|}
\hline & průměr & medián & minimum & maximum & $\begin{array}{c}\text { kvartil } \\
25 \%\end{array}$ & $\begin{array}{c}\text { kvartil } \\
75 \%\end{array}$ & $\begin{array}{c}\text { kvantil } \\
10 \%\end{array}$ & $\begin{array}{c}\text { kvantil } \\
90 \%\end{array}$ \\
\hline Řád toku (Strahler) & 2,8 & 3 & 1 & 5 & 2 & 3 & 2 & 4 \\
\hline Povodí nad lokalitou [km²] & 20,3 & 12 & 0,53 & 175 & 5,8 & 23,6 & 2,6 & 45,4 \\
\hline Nadmořská výška [m] & 397 & 384 & 150 & 850 & 300 & 479 & 255 & 565 \\
\hline
\end{tabular}


abiotických charakteristik (mimo hodnocení změn morfologie toků) a 332 lokalit neovlivněných znečištěním nebo nízkými hodnotami pH, z toho bylo 187 lokalit vyhodnoceno jako PER, 86 jako VUL a 59 jako INT. V analýze byla nastavena krosvalidace a bylo penalizováno chybné prírazení lokalit hodnocených podle bioindikační metody jako VUL a INT k lokalitám PER (tzv. misclassification cost byla zvýšena na dvojnásobek a čtyřnásobek). Byl také nastaven dotaz na existenci alternativních charakteristik (surrogates) pro jednotlivé úrovně dělení. Úroveň klasifikačního stromu, tedy podrobnost dělení, byla vybrána podle označení optimálního stromu ve výsledku analýzy. Výsledky byly hodnoceny podle podílu lokalit jednotlivých typů (PER, VUL, INT) správně zařazených do přislušných skupin a celkové vysvětlené variability v datech. Koncové uzly klasifikace byly analýzou označeny podle nejpočetněji zastoupeného typu lokality. Průkaznost rozdílů v rozložení hodnot charakteristik mezi skupinami lokalit byla testována pomocí Kruskal-Wallisova testu.

\section{Odvození stupně rizikovosti povodí IV. řádu z hlediska vysychání drobných vodních toků}

Jednotlivá povodí IV. rádu byla kategorizována pomocí kombinace abiotických charakteristik a jejich hraničních hodnot ve výsledném klasifikačním stromu $\checkmark$ dané hierarchii. Bylo tedy postupováno po jednotlivých větvích stromu podle hraničních hodnot a povodí bylo zařazeno do kategorie rizika podle prevažujícího typu lokalit v koncovém uzlu (R_0 pro převažující PER, R_1 pro převažující VUL a R_2 pro prevažující INT). Výsledná kategorizace území byla zobrazena $\checkmark$ mapě na úrovni povodí IV. řádu. Byla též vyhodnocena celková homogenita jednotlivých vodních útvarů (vymezených pro ČR pro plánování v oblasti vod) z hlediska zastoupení tři vyhodnocených typů rizika vysychání DVT pro každý útvar.

\section{VYSSLEKY}

\section{Klasifikace lokalit}

Celkem bylo na základě analýz 1368 vzorků makrozoobentosu hodnoceno 332 lokalit. Rozmístění lokalit s odběrem makrozoobentosu je na obr. 1 a jejich základní charakteristiky v tabulce 1 . Hodnocené lokality jsou rozmístěny víceméně rovnoměrně po území celého státu s výjimkou oblastí nejníže položených, kde byla značná část lokalit z výchozího souboru IS SALAMANDER vyloučena pro účely zde prezentovaného hodnocení kvůli znečištění. Pomocí bioindikační metody bylo vyhodnoceno 187 lokalit jako PER (56,3 \%), 86 jako VUL (25,9\%) a 59 jako INT (17,8\%). Hodnoceny byly lokality na tocích I. až V. rádu podle Strahlera, naprostou většinou však II. až IV. rádu. Podíl lokalit INT na tocích I. až III. rádu se pohyboval kolem $20 \%$ (18 až $23 \%$ ), na tocích IV. řádu pak méně (12\%).

Byly porovnávány skupiny lokalit vyhraněných vưči fenoménu vysychavosti - INT a PER (Kruskal-Wallis test); nebyly zjištěny průkazné rozdíly v hodnotách rádu toku, plochy povodí nad lokalitou, stejně ani u výskytu tektonických poruch v povodí, výskytu krasů či pseudokrasů v povodí nebo významných geomorfologických hranic. Průkazný rozdíl mezi těmito skupinami lokalit naopak byl zjištěn pro ukazatele deficitu srážek $(H=45,33 ; p=0,000)$ - větší deficit u INT, podílu jílovců $(H=27,33 ; p=0,000)$ - větší podíl u INT, typu krajinného pokryvu $2(\mathrm{H}=56,33 ; \mathrm{p}=0,000)$ - větší podíl u INT a podílu plochy stojatých vod v povodí IV. řádu $(H=14,66 ; p=0,000)$ - větší podíl u INT. Morfologický stav lokalit INT byl prokazatelně horší než lokalit PER ( $H=66,19 ; p=0,000)$.

$\checkmark$ prípadě 36 lokalit byla doložena epizoda vyschnutí přímo pozorováním a/nebo měřením průtoku $v$ průběhu terénních prací. Z těchto lokalit bylo hodnoceno pomocí bioindikační metody 47,2 \% jako INT, 50 \% jako VUL a 2,8 \% (tedy pouze jedna lokalita) jako PER. Vyplývá z toho, že použitá metoda retrospektivní bioindikace vysychání toku na základě makrozoobentosu měla ve srovnání s reálným výskytem vyschnutí vysokou úspěšnost detekce vyschnutí.

\section{Abiotické charakteristiky pro kategorizaci území}

Kategorizace území byly zpracovány a hodnoceny na úrovni povodí IV. rádu. Pro porovnání rozložení charakteristiky pro celou republiku a $v$ hodnoceném souboru lokalit je u výsledků každé charakteristiky nejprve komentován stav pro celou ČR a vzápětí pouze pro povodí IV. rádu, v nichž se nalézají hodnocené lokality.

Pro potřeby kategorizace ČR z hlediska ohrožení deficitem srážek byla vytvořena mapa, na níž je území rozděleno podle deficitu srážek (převládající evapotranspirace nad srážkami vyjádřené pomocí jednotlivých kvantilů) do deseti kategorií podle četnosti jednotlivých let, $v$ nichž prevládá evapotranspirace nad srážkami. Na obr. 2 je zobrazena výsledná kategorizace území, kde oblast tmavě červená $(0,9$ až 1,0) představuje území, kde ve více než $90 \%$ jednotlivých let hodnoceného období 1961-2011 převládala evapotranspirace nad srážkami, naopak v oblastech s tmavě zelenou barvou $(0-0,1)$ bud' prevládají srážky ve všech letech, popř. evapotranspirace převládá nad srážkami maximálně do $10 \%$ případů, tzn. jen v nejsušších letech.

$\checkmark$ rámci ČR náležela zhruba třetina (35\%) z celkového počtu povodí IV. rádu do oblasti s nejpríznivějšími klimatickými podmínkami $(<0,2)$. Do oblastí, kde jsou častější roky s převažující evapotranspirací $(>0,5)$, spadala také třetina (33\%) hodnocených povodí. Hodnocené lokality se v povodích s nejpř́iznivějšími klimatickými podmínkami $(<0,2)$ vyskytovaly ve $47 \%$ prípadů, poněkud méně se vyskytovaly v povodích s vyšším deficitem srážek (23 \%).

Výskyt jílovců v podloží je geograficky vymezen, vyskytuji se především $\checkmark$ povodí Labe v oblasti České tabule a jihočeských pánví (obr. 3). Nevyskytují se v $72 \%$ povodí v ČR, ve $14 \%$ je pak jejich podíl nadpoloviční. Pro hodnocené lokality byl nadpoloviční podíl jílovců zjištěn ve $20 \%$ povodí a zhruba dvě třetiny z nich (67,5\%) přítomnost jílovců nevykazují, což se blíži situaci v celé ČR.

Výskyt významných hranic mezi geomorfologickými okrsky v povodí (obr. 4) nebyl zjištěn ve více než čtvrtině povodí IV. rádu (29\%), v další čtvrtině (26\%) povodí byla zjištěna hodnota větší než 0,25 . Mimořádně vysoké hodnoty $(>0,50)$ se týkaly necelých $2 \%$ povodí. Pro hodnocené lokality bylo $\vee$ uvedených kategoriích zjištěno zastoupení $17 \%, 41 \%$ a $8 \%$, lokality se tedy častěji vyskytovaly v povodích s vyššími hodnotami této charakteristiky, než odpovídalo rozložení v rámci republiky.

Výskyt krasových a pseudokrasových oblastí (obr. 5) nebyl zjištěn u 69 \% povodí IV. rádu $\vee$ ČR, nadpoloviční podíl se vyskytoval u $18 \%$ povodí v různých částech republiky. Hodnocené lokality se vyskytují v povodích bez krasových nebo pseudokrasových jevư v 59 \% prípadů, nadpoloviční podíl byl zjištěn v 15 \% prípadů, zastoupení je tedy približně srovnatelné se situací v ČR.

výskyt významných tektonických jevů (poruch, zlomů $\vee$ povodí) byl na území ČR detekován ve třetině povodí (34,6\%), více v povodí Moravy a Odry, zejména $\vee$ oblasti Jeseníků a Beskyd (obr. 6). Tyto jevy byly zjištěny $v$ povodích hodnocených lokalit ve 49 \% prípadů, tedy častěji než odpovídalo situaci na celém území ČR.

Typ nepř́znivého krajinného pokryvu (2) se podle očekávání vyskytoval v ČR především v oblastech nížin (obr. 7). Nadpoloviční podíl tohoto typu byl zjištěn pro $45 \%$ povodí IV. rádu a $34 \%$ povodí hodnocených lokalit. Důvodem nižšího zastoupení hodnocených lokalit v povodích s méně příznivým krajinným pokryvem bylo to, že lokality zde se vyskytující nebyly vhodné pro zařazení do analyzovaného souboru kvůli svému znečištění.

Z hlediska podílu ploch uvažovaných stojatých vod (obr. 8), tedy zejména malých vodních nádrží včetně rybníků, bylo zjištěno, že se v ČR nevyskytují v 19,2 \% povodí IV. rádu (týká se většinou horských oblastí). V necelé třetině 


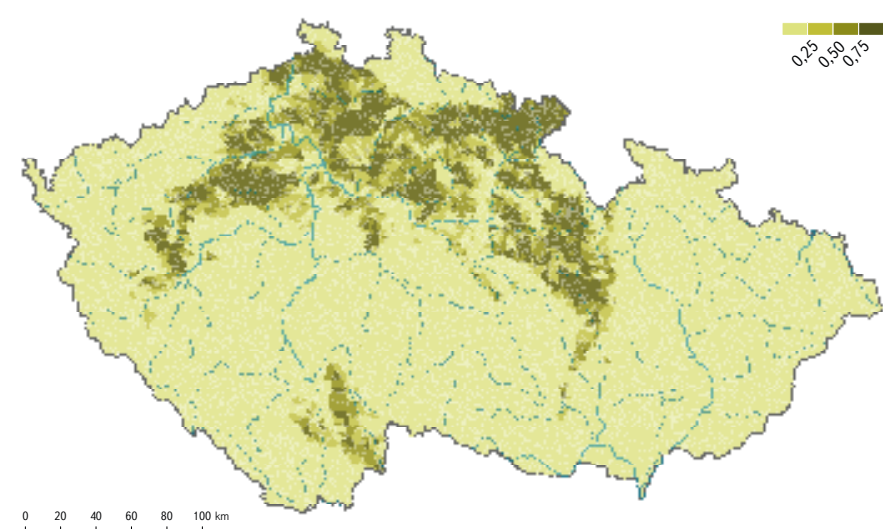

Obr. 3. Mapa podílu jílovců v podloží v povodích IV. rádu

Fig. 3. Map of the share of claystone bedrock in the $4^{\text {th }}$ order catchments

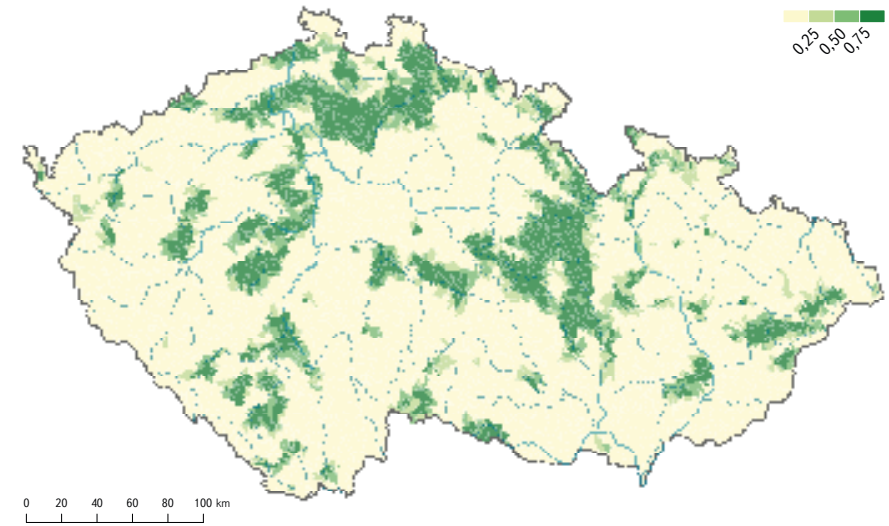

Obr. 5. Mapa podílu krasů a pseudokrasů v povodích IV. rádu

Fig. 5. Map of the share of the karstic and pseudo-karstic areas in the $4^{\text {th }}$ order catchments

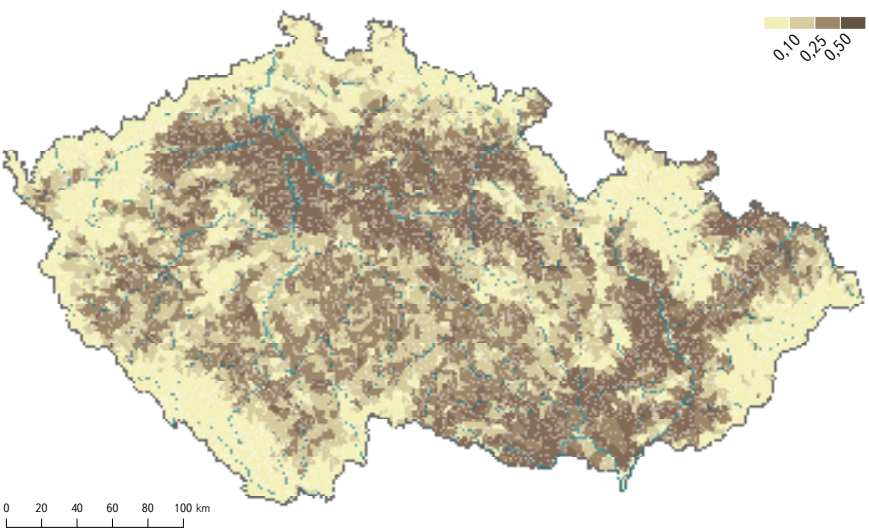

Obr. 7. Mapa podílu nepríznivého druhu povrchu (typ 2) v povodích IV. ráádu; prezentován je podíl nejvíce ovlivněných ploch (CORINE: orná půda, urbanizovaná území a kom plexní systémy kultur a parcel)

Fig. 7. Map of the share of adverse type of land cover (artificial areas, arable land, complex cultivation patterns after (ORINE) in the $4^{\text {th }}$ order catchments

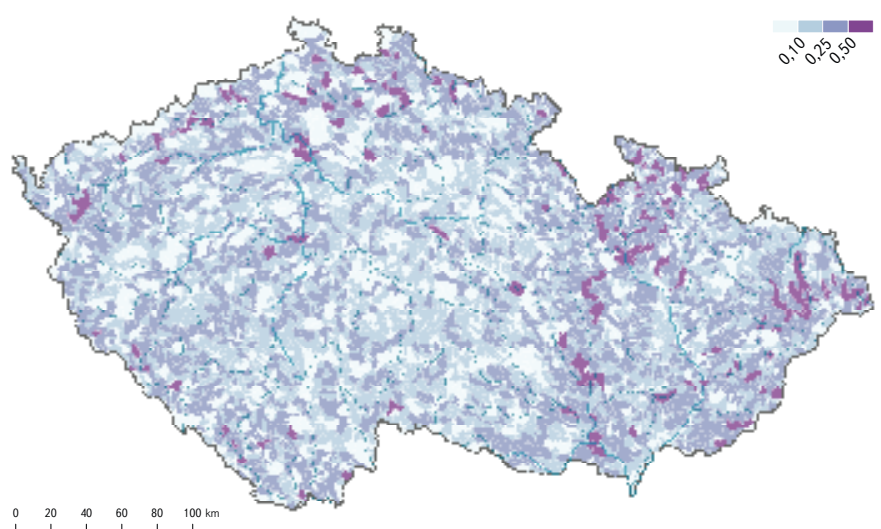

Obr. 4. Mapa výskytu významných geomorfologických hranic v povodích IV rádu Fig. 4. Map of the occurrence of important geomorphological boundaries within $4^{\text {th }}$ order catchments

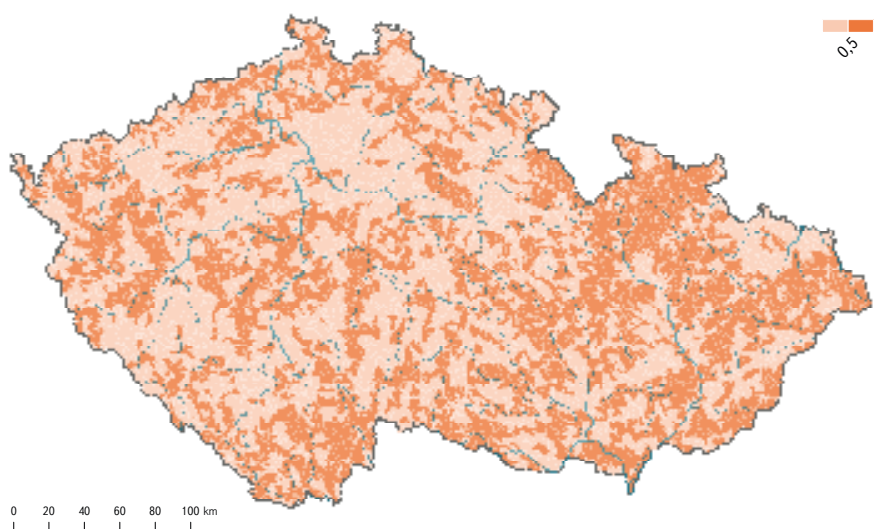

Obr. 6. Mapa výskytu významných geologických poruch a zlomů v povodích IV. rádu Fig. 6. Map of the occurrence of important geological faults in the $4^{\text {th }}$ order catchments

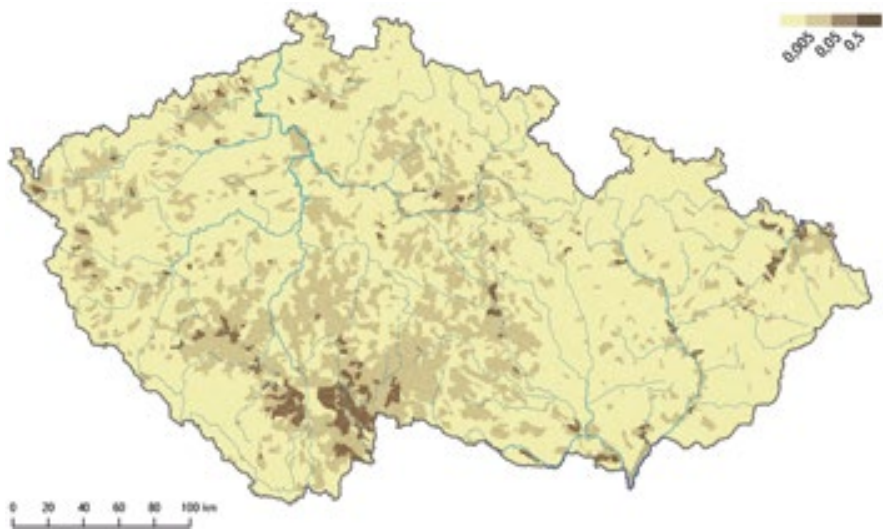

Obr. 8. Mapa podílu ploch vybraných stojatých vod v povodích IV. rádu; do stojatých vod nejsou zahrnuty velké vodní nádrže (se základním objemem větším než 2 mil. m²), z menších nádrží jsou zařazeny nádrže s rekreačním, závlahovým a rybochovným účelem, včetně rybníků

Fig. 8. Map of the share of stagnant water surfaces in the $4^{\text {th }}$ order catchments; large reservoirs (with a basic capacity of more than 2 mil. cubic meters) are not included in the calculation; smaller reservoirs are included only if they serve for recreation, irrigation or fish farming, while fish-ponds are included all 
typ krajinného pokryvu 2 (orná půda, urbaniz. plochy, kompl. pozemky)

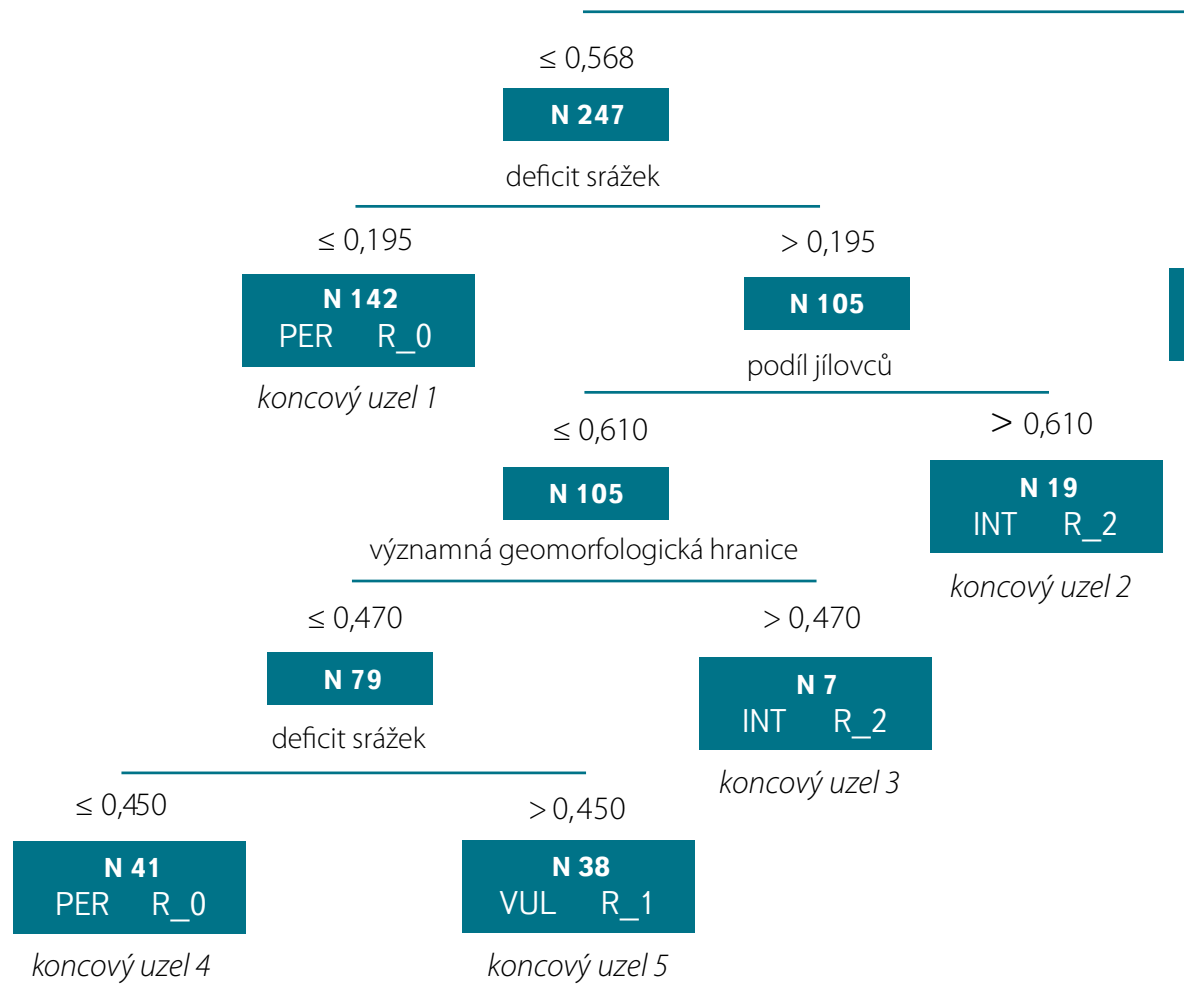

Obr. 9. Klasifikace lokalit PER (toky stále tekoucí), VUL (toky vysychající nepravidelně) a INT (toky vysychající pravidelně) pomocí abiotických charakteristik metodou klasifikačního stromu; $N$ = počet hodnocených lokalit, R_0 nízké riziko vysychání, R_1 střední riziko vysychání, R_2 velké riziko vysychání

Fig. 9. The classification of sites as predicted by the classification tree; site's classification PER, VUL, INT was predicted using abiotic characteristics; PER (permanent) - sites with a constant flow, VUL (vulnerable) - sites with irregular drying up, INT (intermittent) - sites with regular drying up, N = number of evaluated sites, R_0 low risk of drying up, R_1 medium risk of drying up, $\mathrm{R} \_2$ high risk of drying up

(30 \%) povodí tvoří stojaté vody maximálně 0,001 \% plochy. Zhruba $14 \%$ povodí má zastoupení ploch stojatých vod vyšší než 0,01\%. Hodnocené lokality se ve $20 \%$ prípadů nacházely v povodích bez uvažovaných stojatých vod, častěji (40 \% prípadů) byly v povodích s jejich podílem do 0,001 \%, málo (7,5\%) byly zastoupené v kategorii nejvyšší, kde podíl ploch stojatých vod je větší než 0,01 \%.

\section{Klasifikace lokalit jako podklad pro kategorizaci území ČR}

Lokality zatříděné do kategorií INT, VUL a PER byly vyhodnoceny pomocí klasifikačního stromu na základě vybraných charakteristik prostředí. Koncové uzly klasifikace pak byly označeny podle převažujícího typu zařazených lokalit: malé riziko vysychání R_0 pro lokality PER, střední riziko R_1 pro lokality VUL a velké riziko R_2 pro lokality INT). Výsledný klasifikační strom viz obr. 9.

Poměr správně klasifikovaných lokalit byl v př́padě lokalit na obou pólech gradientu vysychavosti (tj. PER a INT) poměrně vysoký (81 \% lokalit PER a 78 \% lokalit INT). Lokality k vysychání vyhraněné méně (VUL) se však do př́slušné kategorie řadily pouze $\vee 38 \%$ prípadů. Menší přesnost hodnocení lokalit typu VUL pak ovlivnila nižší procento celkové vysvětlené variability v datech $(62,8 \%$ ). Nižší spolehlivost klasifikace u střední kategorie je vcelku logická, nebot’ se jedná o přechodný typ mezi dvěma extrémy (permanentní a intermitentní toky), který se v různých sezonách může chovat rozdílně v závislosti na klimatických poměrech.
Při výsledné klasifikaci se uplatnily následující charakteristiky povodí: krajinný pokryv, deficit srážek, podíl stojatých vod, podíl jílovců a výskyt významné geomorfologické hranice. Dvě z charakteristik vstupujících do analýzy (podíl krasů a pseudokrasů a výskyt významných tektonických poruch) vykazovaly nízkou importanci a ve výsledné klasifikaci se neprojevily jako proměnné vysvětlující výraznou část variability. Rozložení charakteristik na území ČR podle hraničních hodnot klasifikace je ž̌ejmé z obr. 10-14.

Hlavní charakteristikou prostředí (na úrovni základního dělení), za kterou nebyla v analýze uvedena zástupná charakteristika, byl typ krajinného pokryvu, respektive podíl námi definované kategorie 2 v povodí IV. rádu.

Pokud podíl půdního pokryvu typu 2 (s dominantním podílem orné půdy) nebyl výrazněji převažující ( $\leq 0,568$, obr. 10, tj. levá strana stromu), jevil se jako významná charakteristika povodí deficit srážek (hraniční hodnota 0,195), přičemž alternativou pro deficit srážek je podíl typu 2 krajinného pokryvu s hraniční hodnotou 0,220. Náleží-li povodí do této klimaticky nejpříznivější oblasti ( $\leq$ 0,195, obr. 11), naprosto převažují lokality PER (121 ze $142 \vee$ tomto koncovém uzlu č. 1). Znamená to, že dvě třetiny všech lokalit vyhodnocených jako PER jsou zařazeny do této větve klasifikace, převážně se jedná o lokality ve vyšších polohách (cf. obr. 1). Koncový uzel č. 1 reprezentuje malé riziko R_0. Do této skupiny však byly zařazeny také některé lokality INT se specifickým charakterem, např́iklad potok Obloučník (prítok Vidnávky) poblíž obce Vápenná v Jeseníkách, který leží v krasovém území, ovlivňujícím jeho hydrologický režim. 


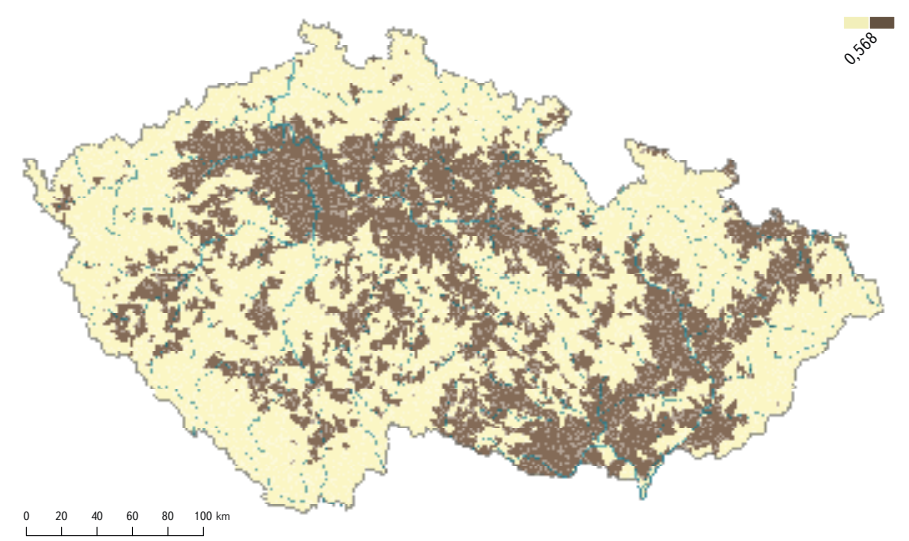

Obr. 10. Mapa podílu nepřiznivého druhu povrchu kategorie 2 v povodích IV. rádu; zobrazuje hodnoty hraniční pro kategorizaci území (obr. 9)

Fig. 10. Map of the share of adverse type of land cover (artificial areas, arable land, complex cultivation patterns after CORINE) in the $4^{\text {th }}$ order catchments; borderline values used in the classification tree are displayed (fig. 9)

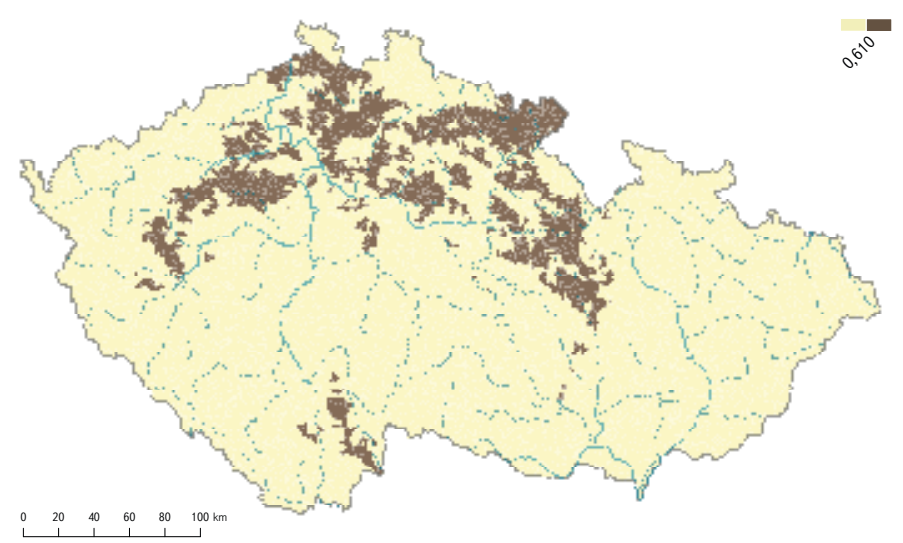

Obr. 12. Mapa podílu jílovců v podloží v povodích IV. rádu; zobrazuje hodnoty hraniční pro kategorizaci území (obr. 9)

Fig. 12. Map of the share of claystone bedrock in the $4^{\text {th }}$ order catchments; borderline values used in the classification tree are displayed (fig. 9)

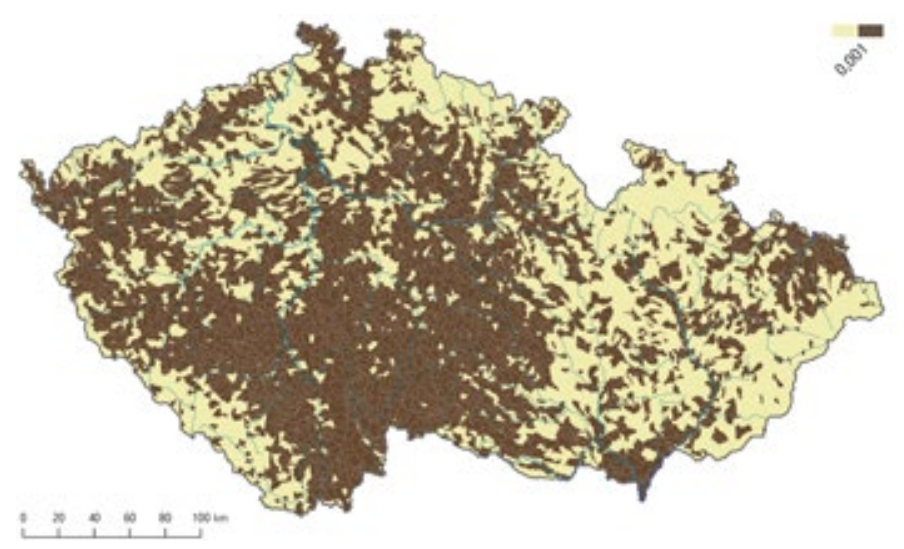

Obr. 14. Mapa podílu vybraných stojatých vod v povodích IV. rádu; zobrazuje hodnoty hraniční pro kategorizaci území (obr. 9)

Fig. 14. Map of the share of selected stagnant surface waters in the $4^{\text {th }}$ order catchments (for explanation see Fig. 8); borderline values used in the classification tree are displayed (fig. 9)

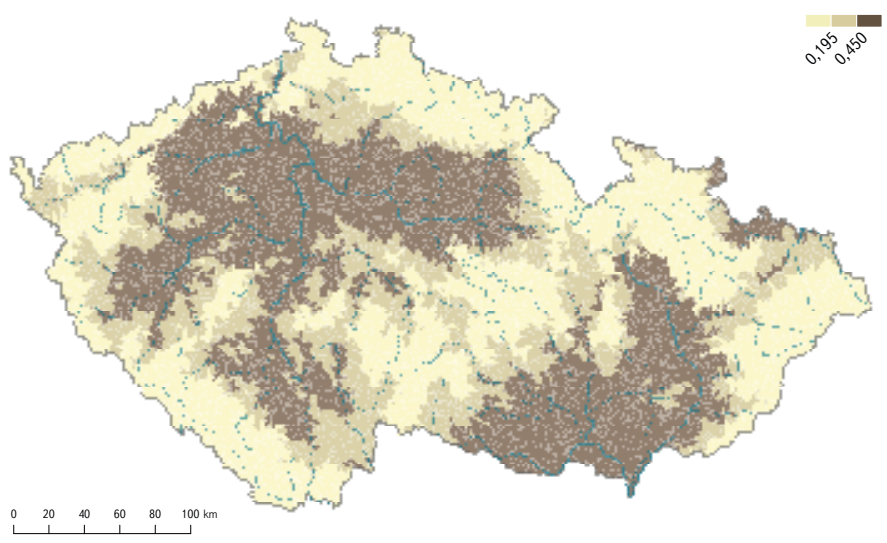

Obr. 11. Mapa deficitu srážek v povodích IV. rádu; zobrazuje hodnoty hraniční pro kategorizaci území (obr. 9)

Fig. 11. Map of the rainfall deficit; for explanation see fig. 2; borderline values used in the classification tree are displayed (fig. 9)

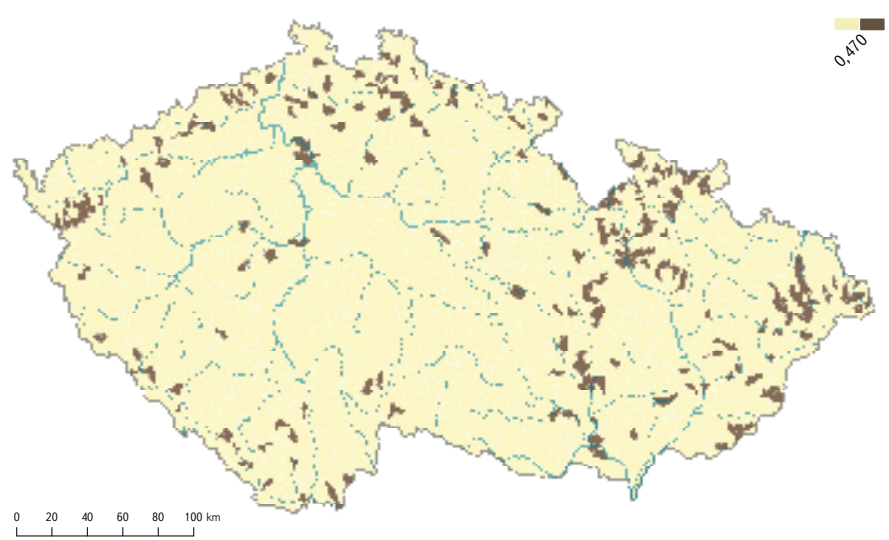

Obr. 13. Mapa výskytu významných geomorfologických hranic v povodích IV. rádu; zobrazuje hodnoty hraniční pro kategorizaci území (obr. 9)

Fig. 13. Map of the occurrence of important geomorphological boundaries within $4^{\text {th }}$ order catchments; borderline values used in the classification tree are displayed (fig. 9) 


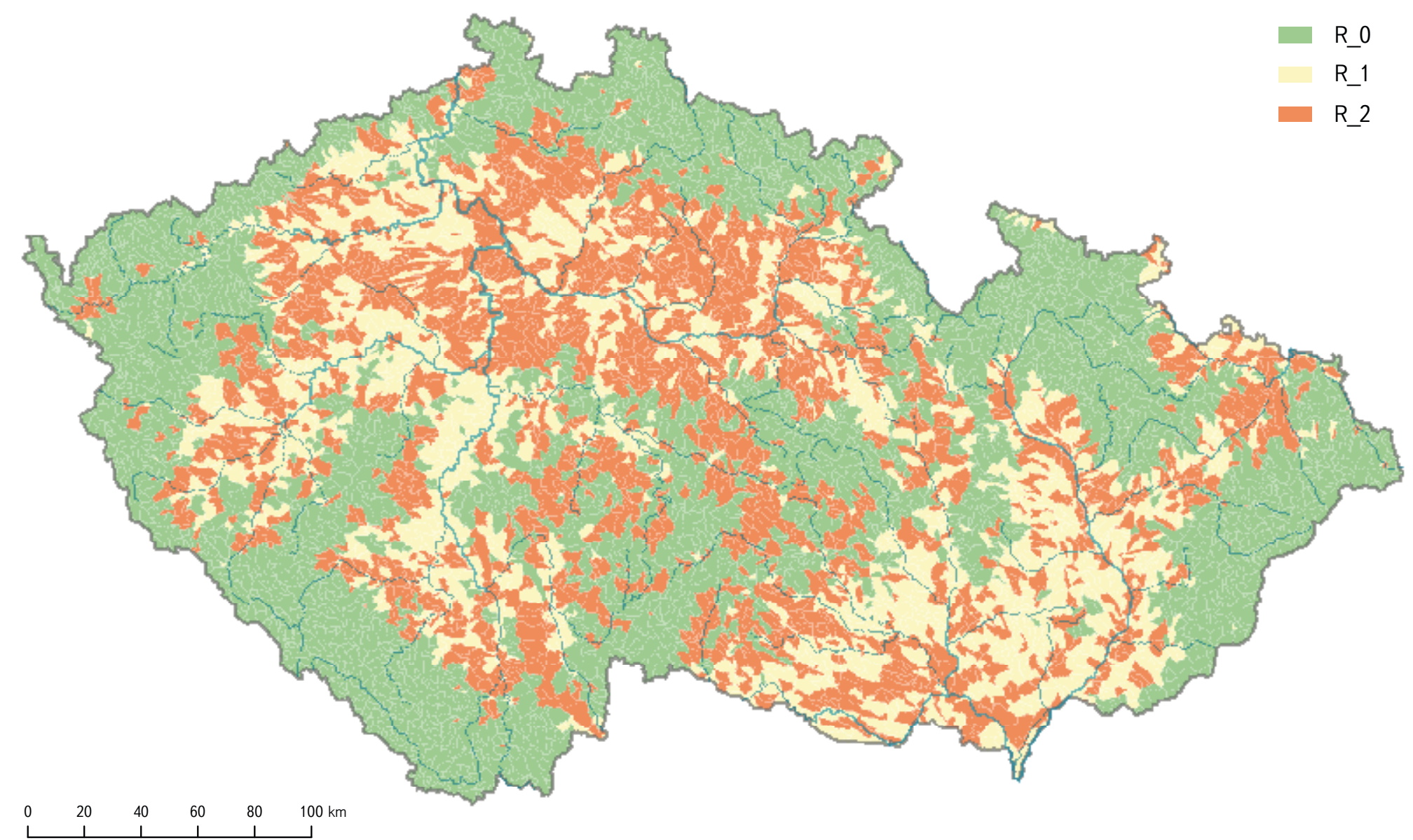

Obr. 15. Kategorizace území České republiky podle míry rizika vysychání drobných vodních toků; odvozeno od výsledků klasifikace lokalit metodou klasifikačního stromu; R_0 malé riziko, R_1 střední riziko, R_2 velké riziko vysychání drobných vodních toků

Fig. 15. The categorization of the Czech Republic area according to the risk of drying up of small streams as predicted by the classification tree (see Fig. 9); $\mathrm{R} \_0$ low risk,

R_1 medium risk, R_2 high risk of drying up of small streams

Pro levou stranu stromu dále platí, že v povodích, jež spadají do oblastí, $\vee$ nichž byl deficit srážek již častější $(>0,195)$, jevil se významným podíl jílovců $\checkmark$ podloží (obr. 12). Pokud tento přesahoval hodnotu 0,610, v koncovém uzlu č. 2 převažovaly lokality INT (11 ze 17) a riziko je hodnoceno jako velké (R_2). Príkladem může být Očihovecký potok (přítok Blšanky) u obce Strojetice na Rakovnicku. Pokud byl deficit srážek častější $(>0,195)$, ale podíl jílovců nižší $(\leq 0,610)$, oddělilo se několik lokalit v povodích s významnou geomorfologickou hranicí (> 0,470, obr. 13) do koncového uzlu č. 3, který reprezentoval velké riziko (R_2). Do tohoto uzlu náleží např. lokalita na potoce Rakovec pobližz obce Bukovinka na pomezí Moravského krasu a Drahanské vrchoviny, na níz vysychá úsek v délce několika km právě v oblasti této hranice.

Ve zbývající části této levé větve klasifikačního stromu zůstává 79 lokalit, které se pak dělí podle deficitu srážek (hraniční hodnota 0,450) na téměř stejně početné části (41 a 38 lokalit), přičemž v oblastech s nižšími srážkovými deficity převažují lokality PER a tento uzel č. 4 reprezentuje malé riziko (R_0). Př́kladem mohou být např. permanentní toky Ohrozima poblíz obce Hrabyně v povodí Opavy nebo Pašínovický potok nad obcí Pašínovice v povodí Stropnice, oba v zalesněných povodích bez nádrží. Uzel č. 5 s vyššími deficity srážek a s vyšším počtem lokalit VUL pak představuje riziko střední (R_1). Do této skupiny lokalit patří např. Podhrázský potok u obce Zdemyslice (př́tok Úslavy), v jehož povodí je nadpoloviční podíl nepríznivého krajinného pokryvu (0,560), což je hodnota, která se blízí hodnotě základního dělení.
Na pravé straně základního dělení klasifikačního stromu v povodí IV. řádu převažovala $(>0,568) \vee$ ploše povodí orná půda, popřípadě urbanizované území anebo komplexní systémy pozemků a parcel. V koncových uzlech této pravé strany stromu se nacházely větve s převahou lokalit typu VUL a INT. Další charakteristikou $v$ této větvi dělení byl podíl ploch stojatých vod $v$ povodí (obr. 14). Pokud byl podíl těchto ploch menší než 0,001 (uzel č. 6), převažovaly lokality VUL a uzel reprezentoval riziko střední (R_1), príkladem mủže být lokalita na Sloupnickém potoce (přítok Loučné) pod obcí Tisová. V tomto případě se jedná o větší tok a ve vyšších částech jeho povodí je rybniční soustava.

Pokud byl podíl ploch stojatých vod v povodí vyšší ( $\geq 0,001$, tedy $1 \%$ ), byla již polovina lokalit (31 z 61) řazených do tohoto koncového uzlu č. 7 označena jako INT, lokalit VUL bylo 18. Tento koncový uzel reprezentoval riziko velké (R_2). Nepatřily sem však pouze lokality v povodích v nížinách a s velkým deficitem srážek, jak by se dalo předpokládat, ale i lokality na tocích v nadmořských výškách bližících se $500 \mathrm{~m}$ n. m., v oblastech chladnějších a bez výrazných srážkových deficitů, jako je např. Doberský potok (přitok Sázavy) u Přibyslavi. 


\section{Kategorizace území ČR podle rizika vysychání drobných vodních toků}

Kategorizace území byla provedena pro 8286 povodí IV. rádu (celá ČR) postupem uvedeným $v$ metodice. Bylo tedy postupováno po jednotlivých větvích klasifikačního stromu a podle kombinací hraničních hodnot charakteristik prostředí bylo každé povodí zařazeno do kategorie rizika stanoveného pro koncový uzel klasifikace. Riziko bylo odvozeno podle převažujícího typu lokalit (R_0 pro PER, R_1 pro VUL a R_2 pro INT).

Výsledná klasifikace území je zobrazena $v$ mapě na úrovni povodí IV. raádu (obr. 15). Podle této kategorizace je 44,5\% z celkového počtu povodí IV. ̌rádu hodnoceno jako území s malým rizikem vysychání DVT (R_0), pro 29,4\% povodí bylo stanoveno riziko střední (R_1). Zbývajících 26,1\% je pak označeno jako území s rizikem velkým (R_2).Z hlediska plochy to pak predstavuje 45,3 \%, 23,3 \% a 31,3\% rozlohy ČR.

Byla též vyhodnocena homogenita vodních útvarů povrchových vod tekoucích z hlediska rizika vysychání DVT. Přibližně polovina (53,4 \%) vodních útvarů má jednoznačné zařazení do kategorie rizika, je však třeba uvést, že téměř třetina vodních útvarů je tvořena jen jedním povodím IV. rádu. Z těchto jednoznačně kategorizovaných vodních útvarů bylo 42,9\% z celkového počtu vodních útvarů v kategorii R_0, $7 \%$ v R_1 a 3,5\% v R_2. Zbývající útvary pak byly tvořeny povodími, klasifikovanými do dvou nebo do všech tří kategorií rizika (cca 28 \% a 18 \%).

\section{DISKUSE}

Kategorizace území ČR byla založena na analýze vstupního souboru dat o biotické složce toků - makrozoobentosu. Tato skupina organismů je považována za vhodnou pro indikaci různých typů vlivů v tocích $[1,33]$. Nově vyvinutá metoda retrospektivní indikace vykazovala při použití na souboru dat z projektu BIOSUCHO spolehlivost téměř 90 \% správné klasifikace při zařazení vzorků do kategorii permanentní (PER) nebo vysychavý (INT) tok. Při zařazení do přechodné kategorie vysycháním zranitelný tok (VUL) pak cca 70 \% [34], přičemž u všech hodnocených odběrů bylo možné ověřit rozsah a trvání epizody vyschnutí exaktně měřenými daty z terénu. Spolehlivost detekce vyschnutí toků pomocí této bioindikační metody je tedy vysoká.

Soubor dat z IS SALAMANDER nebyl původně určen pro hodnocení frekvence vysychání a přesně změřená a soustavná data o délce trvání a rozsahu vyschnutí nejsou pro tuto databázi k dispozici. Nicméně se jedná o unikátní soubor výsledků analýz, měření a pozorování na velkém počtu lokalit $\checkmark$ období druhé poloviny 90 . let 20 . století (v prípadě většiny minimálně ovlivněných lokalit) a s převážně víceletým sledováním dalších lokalit během prvni dekády tohoto století. Jedná se tedy o období, kdy se již začaly výrazněji projevovat klimatické změny. Hodnocení vzorků makrozoobentosu z odběrů provedených ZVHS bylo možno ověrovat pomocí srovnání se záznamy o reálném průtoku od vzorkařů, kteří většinu lokalit navštěvovali v měsíčních intervalech. Pozorované epizody vyschnutí tedy nemusely být zaznamenány vždy, pokud šlo o epizody kratší než měsíc, tedy $\vee$ prípadě vzorků, které poté byly pravděpodobně vyhodnoceny jako VUL. Detekce kratších epizod vyschnutí pomoci bioindikace je také poněkud obtižnější, proto byl převod hodnocení jednotlivých vzorků na hodnocení lokalit nastaven s určitou obezřetností ve smyslu eliminace falešně pozitivních výsledků (tj. indikace vyschnutí, které však ve skutečnosti nenastalo). Jako VUL byla lokalita hodnocena, jestliže tento stav byl detekován nejméně u dvou vzorků (tj. sezon) za období sledování (popř. byl jednorázově zjištěn stav INT a ostatní vzorky byly hodnoceny jako PER). Lze tedy předpokládat, že pokud už byla lokalita klasifikována jako VUL, k určité, byt kratší epizodě vyschnutí na ní došlo. Při analýze v klasifikačním stromu bylo na druhou stranu penalizováno chybné zařazení lokalit INT i VUL: jestliže již byla lokalita označena jako více či méně vysychavá, neměla by být řazena do koncových uzlů klasifikace, reprezentujících malé riziko (R_0) ve smyslu falešně negativního výsledku. Tato dvě opatření měla vést k objektivizaci výsledné kategorizace území z hlediska rizika vysychání.

Podle výsledků navržené kategorizace je téměř na polovině území ČR (45,3\%) riziko vysychání toků malé a na čtvrtině střední (23,3\%). Pro téměř třetinu území (31,3\%) je však riziko odhadováno jako velké. Míra rizika daného území jednoznačně souvisí s podílem nepríznivého typu krajinného pokryvu 2, většinově reprezentovaném podílem orné půdy. Podíl orné půdy v ČR souvisí s klimatickými podmínkami a ty zase s nadmořskou výškou. Není tedy překvapivé, že malé riziko vysychání toků je převážně v územích nad hranicí 500 m n. m. Typ krajinného pokryvu 2 souvisí také s morfologickým stavem toků - v zemèdělsky intenzivně využívaných i v urbanizovaných oblastech je napřimování a i opevňování toků mnohem častější než v ostatních územích. V hodnoceném souboru byl podíl významně morfologicky ovlivněných toků v oblastech s nižším podílem krajinného pokryvu typu $2(\leq 0,568$, cf. obr. 9) jen 3,3\%, zatímco v oblastech $s$ jeho vyšším podílem to bylo $27 \%$. Vliv regulace toků na zvýšení náchylnosti toků k vysychání je mnohokrát doložen [1] a je již všeobecně akceptován [9].

Vliv klimatických jevů na riziko vysychání je zřejmý - výskyt a množství srážek a míra evapotranspirace jsou standardně užívány při hodnocení sucha za použití různých metod [2]. Námi zvolený přístup odvození mapy deficitu srážek má výhodu v tom, že bude možné (i) mapu jednoduše aktualizovat na základě novějších dat z řad údajů v gridové síti a (ii) nastavovat míru podrobnosti kategorizace.

Vztah průtoků včetně nulových $\mathrm{k}$ dalším charakteristikám prostředí je již komplikovanější. Při hodnocení nedostatkových průtoků na základě dat z hydrologických stanic [18] autoři citované studie nenalezli, s výjimkou vazby k podílu jílovců v podloží, průkaznou vazbu ke sledovaným charakteristikám prostředí (krajinný pokryv, další typy podloží). Možným důvodem je to, že hodnoceny byly větší toky, které si z hlediska průtokových režimů uchovávají hydrologický režim z vyšších částí povodí [16], zatímco toky nižších řádů jsou závislejší na lokálních podmínkách, a vazbu tedy Ize snáze detekovat. Např́klad pokud povodím prochází významná hranice mezi okrsky geomorfologického členění, znamená to obvykle, že toky jednak mění spád, jednak se často dostávají na hranice geologických jednotek, což může být spojeno např́klad se změnou propustnosti. Typickou situací je jakési zanoření určitého úseku toku, napríklad do kvartérních sedimentů o vyšší mocnosti nebo podloží z různých příčin propustnějšího, např. na hranici krasových oblastí. Na hranicích okrsků se v řadě prípadů vyskytují také tektonické poruchy, které vedou k tomu, že povrchový průtok na určitém úseku vymizí. Př́kladem může být úsek toku Luha nad obcí Sloup na hranici Moravského krasu.

Výskyt oblastí s krasovou propustností a existence tektonických poruch jsou důležitými prírodními podmínkami ovlivňujícími vodnost DVT. Obojí úzce souvisí se ztrátou vody z povrchového toku, ale i s její dotací z podzemní vody v krasových oblastech jsou propadání i vývěry, také tektonické poruchy mohou působit obousměrně. Nejednoznačné byly z tohoto pohledu i výsledky hodnocení těchto charakteristik v použitém souboru dat. I z těchto důvodů nebyly charakteristiky podíl krasů a pseudokrasu a výskyt tektonických poruch zohledněny ve výsledné zobecněné mapě rizika. Z hlediska předběžné opatrnosti je však třeba při posuzování situace $v$ povodí prihlédnout i $k$ výskytu těchto jevů. Zejména v oblastech krasových, ale i pseudokrasových, kterých je v ČR poměrně dost (obr. 5), jedná se např. o oblasti pískovcových skalních měst, dochází k vysychání toků často [35]. Př́kladem intermitentního toku v oblasti, kde nepůsobí jiné negativní vlivy než krasové podloží a existence tektonické poruchy, je již zmiňovaný potok Obloučník poblíz Vápenné.

Z antropogenních vlivů mimo výše uvedený typ krajinného pokryvu má zcela jistě závažný vliv intenzita odběrů vody jak prímo z toků, tak z vod podzemních. Informace o odběrech a vypouštění vod jsou však centrálně evidovány až od určitého objemu. V databázi HEIS jsou podchyceny odběry od objemu přesahujícího $6000 \mathrm{~m}^{3}$ za rok, resp. $500 \mathrm{~m}^{3}$ za měsíc a data z této databáze testovaná autory v předchozích výzkumech nevykazovala souvislost s vysycháním DVT. Vliv centrálně neevidovaných odběrů vody, at již napríklad z potoků pro 
závlahy zahrad, nebo vrty zásobujícími pitnou vodou jednotlivé obce, zemědělské podniky či rekreační objekty, byl však zjevný jak při podrobném hydrogeologickém hodnocení vybraných lokalit [19], tak při terénních průzkumech. Tento jev, navíc značně proměnlivý v čase, však nelze objektivně hodnotit tak, aby vznikla vrstva GIS použitelná pro kategorizaci území, zčásti je však velmi pravděpodobně podchycen při kategorizaci krajinného pokryvu v položkách urbanizovaná území a komplexní systémy kultur a parcel.

Jako situace vedoucí k častému výskytu vysychání DVT byla vyhodnocena kombinace vysokého podílu typu 2 krajinného pokryvu a relativně vysokého podílu ploch stojatých vod v povodí IV. rádu. Do koncového uzlu č. 7 (cf. obr. 9), který tuto kombinaci podmínek představuje, byla zařazena více než polovina (31 z 59) lokalit klasifikovaných pomocí bioindikační metody jako INT.

Pokud hodnotíme celý soubor 332 lokalit, pak z celkového počtu 59 lokalit klasifikovaných jako INT se nacházelo 43 v povodích s podílem ploch stojatých vod v průměru cca $7 \%$ (průměrný podíl nepříznivého krajinného pokryvu typu 2 byl $59 \%$ plochy povodí pro lokality INT). Pro lokality PER tyto hodnoty odpovídaly $3 \%$ a $26 \%$. Pro obě charakteristiky byl zjištěn průkazný rozdíl mezi PER a INT lokalitami (viz Výsledky).

Tento výsledek, možná překvapivý, je však logicky vysvětlitelný. Pro drobné vodní toky jsou z hlediska ovlivnění průtokového režimu významné malé vodní nádrže (MVN), budované predevším pro účely závlah, rekreace a chovu ryb. Vlivu MVN, zejména rybničního typu, na hydrologický režim drobných toků nebyla v ČR věnována př́liš velká pozornost, ačkoliv jejich počet je v naší zemi velmi vysoký, jen rybníků je v různých zdrojích udáváno kolem 20000 [36]. V běžných typech MVN jde primárně o zadržení vody v nádrži pro nějaký ekonomický účel a z toho důvodu obvykle také o udržení určité kóty hladiny, poprípadě o nárazové vypouštění v podzimních měsících (výlovy rybníků). $\vee$ teplých a suchých obdobích dochází, zejména z důvodu zachování dostatečného objemu vody např. pro přežití ryb, k zadržování vody v nádržích, v tomto období dochází také zajisté k nezanedbatelnému odparu z hladiny [37], který může i převýšit př́itok. Pokles hladiny vody v nádrži vede také $\mathrm{k}$ většímu prohřívání vody s dopady na jakost vody nejen v samotné nádrži, ale následně i v toku pod hrází. Zajištění stálého průtoku pod nádrží zjevně nebývá v praxi při manipulaci prioritou, což odpovídá zkušenostem z terénních pozorování autorů. K situacím, že voda zadržená v nádržích není v období sucha vypouštěna, dochází nejen ve vzdálených aridních oblastech nebo bližším evropském mediteránu [38], ale i v podmínkách ČR. Dokladem toho může být mimo jiné i reakce na extrémní sucho v roce 2015 ve smyslu zvýšení kontrol zaměřených na dodržování manipulačních rádů a zajištění minimálních zůstatkových průtoků v tocích (viz např. www.cizp.cz).

\section{Srovnání map kategorizací území ČR ve vztahu k vysychání}

Výslednou kategorizaci území, předkládanou v této práci, je možno srovnávat s řadou kategorizací ČR ve vztahu k jevům klimatickým, hydrologickým a zemědělským i socioekonomickým rizikům spojeným se suchem, které jsou k dispozici v mapové podobě. Pro konkrétní srovnání jsou pak nejvhodnější mapy zobecněné, postihující dlouhodobý stav nebo rizika.

Ve srovnání s mapami klimatickými, např. průměrných ročních nebo červencových teplot vzduchu či průměrného ročního úhrnu srážek, vykazuje mapa rizika vysychání DVT rámcovou shodu ve vymezení malého rizika v oblastech srážkově příznivějších, stejně jako ve vymezení velkého rizika na jihu Moravy, České tabule a Podkrušnohorské oblasti. Rozdílné je však hodnocení v oblasti Západobeskydského podhưří (výrazné změny reliéfu, častější tektonické poruchy, nepříznivější krajinný pokryv) a/nebo i chladnějších (část Českomoravské vrchoviny s vyšším podílem orné půdy a vodních ploch), které podle námi navrhované kategorizace patří k oblastem s velkým rizikem vysychání DVT. Prevážně velké riziko vysychání DVT bylo námi stanoveno také pro část oblasti
Jihočeských pánví a části Středočeské pahorkatiny, které jsou např. podle podílu hodnot odvozených od významné metriky pro hodnocení zemědělského sucha, Palmerova Z-indexu [2, 12] klasifikovány většinou do středních nebo nižších hodnot z hlediska frekvence výskytu sucha.

Pro srovnání s výsledky hydrologických hodnocení jsme použili mapu trendů ročních standardizovaných nedostatkových objemů vymezených prahovým průtokem Q95 v období 1961-2007 (varianta pro přirozené průtoky) [18]. Rostoucí trend, tedy silnější tendence ke zvětšování sucha, byl zjištěn na některých stanicích v horní části povodí VItavy, střední části povodí Sázavy, v povodí Orlice a početněji také u řeky Moravy. To je ve shodě s námi navrhovanou kategorizací, ačkoliv hydrologická hodnocení se týkají větších toků. Jako stanice bez trendu byly hodnoceny ty, které se nacházejí v povodí Berounky a Dyje, tam se mapa kategorizace pro DVT odlišuje.

Mrkvičková a Balvín [16] navrhli kategorizaci území ČR do čtyř typů oblastí v závislosti na charakteru hydrologického režimu a na klícových procesech, které se $v$ dané oblasti podílejí na tvorbě odtoku. Toto členění bylo vytvořeno pro návrh variantního postupu stanovení minimálních zůstatkových průtoků v tocích. Zohledňuje mimo hydrologické charakteristiky také hydrogeologické poměry a nadmořskou výšku a zavádí parametr v podstatě vystihující vyrovnanost (rozkolísanost) průtoků $v$ tocích. $Z$ našeho hlediska to Ize chápat jako určité měřítko náchylnosti toků k vysychání. Kategorie 4 navržená citovanými autory, tedy s průtoky nejvíce rozkolísanými, do značné míry odpovídá oblastem s velkým či středním rizikem vysychání DVT podle kategorizace předkládané v naší studii. Rozdílné je hodnocení v území hydrogeologického rajonu 4710, 4720 a 4730 bazálních křídových kolektorů a také některých základních rajonů, obvykle také ve vazbě na křídu, které jsou v práci Mrkvičkové a Balvína [16] hodnoceny jako př́iznivé, nicméně z hlediska naší kategorizace jsou hodnoceny odlišně. V oblasti bazálních křídových kolektorů je objektivně nízká hustota říční sítě a vysoká propustnost podloží, má zčásti pseudokrasový charakter. Na DVT zde dochází k epizodám vyschnutí (např. Olešnička, př́tok Kamenice, u obce Stará Oleška, srpen 2003 a 2004).

Pro hodnocení socioekonomického sucha existuje řada postupů, používané ukazatele však vedou k tomu, že s kategorizací DVT podle rizika jejich vysychání souvisí jen zčásti. Zajímavé je srovnání s výsledky multikriteriální analýzy definující katastry nejvíce ohrožené suchem a prívalovými srážkami, zpracované pro Generel vodního hospodářství v ČR [2], kdy se námi navrhovaná kategorizace podobá mapě prezentující hodnoty průměrného z-skóre, které v tomto generelu udává míru ohrožení území suchem.

Jako kategorizace nejbližší námi vytvořené variantě se jeví mapa zranitelnosti území ČR vưči suchu v závislosti na ročním výskytu stresu suchem [2], která je mimo jiné založena na schopnosti ekosystémů poskytovat ekosystémové služby v závislosti na ročním výskytu stresu suchem. Podobnost obou návrhů může být dána mimo jiné tím, že v ekosystémovém pojetí je zahrnuta i fragmentace krajiny.

\section{Výstižnost a možnosti využití navrhované kategorizace drobných vodních toků}

Navrhovaná kategorizace je založena na analýze společenstev živých organismů, což vždy prínáší určitou míru variability v datech. Spolehlivost vymezení oblastí je přibližně 80 \% z hlediska výskytu úseků toků permanentních nebo intermitentních. Nutno říci, že vzhledem k významné roli lokálních podmínek není reálné postihnout všechny faktory, vedoucí $k$ faktickému vyschnutí určitého, v některých prípadech jen relativně krátkého úseku toku. Kategorizaci území proto nelze brát zcela striktně v tom smyslu, že všechny toky v území s velkým rizikem v období sucha vyschnou a naopak, že v oblastech s malým rizikem nemůže vyschnutí toků nikdy nastat. I tam může napřiklad při souběhu nepřiznivých klimatických podmínek a nevhodných zásahů člověka docházet k vysychání toků, jak tomu bylo právě v roce 2015 [8].

Navrhovaná kategorizace bude $v$ podobě interaktivní mapy $k$ dispozici na webových stránkách HEIS. Pro každé povodí IV. rádu bude zobrazen stupeň 
rizika vysychání DVT a uvedeny charakteristiky, které riziko definují, včetně upozornění na to, zda se na území povodí vyskytují krasy, pseudokrasy a významné tektonické poruchy jako potenciálně rizikové faktory, které mohou spolupůsobit při vyschnutí koryta na konkrétním úseku.

Výsledná mapa má za cíl doplnit rưzné náhledy na rizika spojená s výskytem sucha, a to pro DVT, což bylo téma dosud opomíjené, ačkoliv ČR je zemí s jejich relativně vysokým podílem v říční síti. Podklad je využitelný prí rozhodováni $\checkmark$ různých resortech, zejména při rozhodování o nakládání s vodami a o prioritách při alokacích prostředků pro boj se suchem, stejně jako pro územní plánování či ochranu ekosystémů.

$\checkmark$ tomto kontextu je třeba zdůraznit, že jako hlavní faktor, vedoucí k vysychání DVT, byla detekována kombinace převažujícího nepříznivého typu krajinného pokryvu a vyššího podílu vodních ploch - malých vodních nádrží. Pokud se týká nádrží, nejedná se o překvapivý výsledek, který by nebyl z odborné literatury znám. Jev je doložen z oblastí s aridním klimatem, jako je jižni Austrálie a jižní Afrika [1], ale i z evropské temperátní zóny - povodí Loiry [39]. Kumulativní vliv malých nádrží v povodí mưže vést ke snižení prưměrných ročních průtoků zhruba o $20 \%$ v aridních oblastech a o cca $7 \%$ v mírném pásmu [39]. Lake [1] uvádí, že omezení objemu vody zadržované v těchto nádržích může být důležitým opatřením ke zmírnění negativních vlivů sucha. Je tedy třeba pečlivě zvažovat výběr opatření v boji proti suchu, zejména těch, která mají vést k zadržování vody v krajině. Existence nádrží sice pomůže vytvořit disponibilní zásobu vody, nicméně z hlediska vodního režimu samotného toku i okolní krajiny to však může situaci zhoršit [40]. Lapidárně řečeno, voda zadržená v malé nádrži je vodou zadrženou v nádrži, nikoliv v komplexní struktuře krajiny, která ji může postupně uvolňovat a omezovat tak rizika úplného vyschnutí koryta toku i půdy v povodí. Při využívání malých nádrží je dalším problémem snaha o víceúčelovost. Sladit např́klad požadavky pro chov ryb a zachování minimálního zůstatkového průtoku se v období sucha může snadno stát nemožným.

Lake [1] uvádí jako postup vedoucí ke zvýšení rezilience a rezistence akvatických ekosystémů vůči suchu návrat k přirozeným průtokovým režimům nebo alespoň zajištění tzv. environmentálních průtoků (tj. minimální zůstatkové průtoky), obnovu podélné i príčné konektivity toku, umožnění povodňových rozlivư k doplnění zásob podzemní vody a samožrejmě renaturaci či revitalizaci toků a vhodný management využití krajiny. Je zřejmé, že se jedná o procesy, které jsou z hlediska realizace jednak poměrně obtí̌né, jednak obvykle časově náročné. Usnesení vlády k prípravě realizace opatření pro zmírnění negativních dopadů sucha a nedostatku vody, které má vést $k$ vytvoření koncepce ochrany před následky sucha, dává prostor pro racionální výběr těchto opatření. $\vee$ povodích drobných vodních toků s převažujicí ornou pưdou jsou zřejmě zásadní opatření v krajině, zejména ve zpưsobu hospodaření. Na prvním místě by tedy mělo být zhodnocení současného stavu se zohledněním rizika vysychání toků a ekonomicky odůvodněný propočet přínosů navrhovaných opatření ve vztahu k nákladům. Prírodě bližší a často levnějši opatření jako renaturace, popř. revitalizace toků, obnova mokřadů a vhodné pozemkové úpravy tak mohou být výrazně prínosnějším a ekonomičtějším opatřením než masivní výstavba dalších menších nádrží. Ty v období sucha průtoky v našich drobných vysychajících tocích nadlepšovat zřejmě nebudou, spíše naopak.

\section{Poděkování}

Autoři děkuji podniku Povodi Moravy, s. p., za zprístupněni dat z informačního systému SALAMANDER, bez kterých by tato studie nemohla vzniknout. Českému hydrometeorologickému ústavu děkují za souhlas s využitím klimatických dat zpracovaných do údajů v gridové siti. V neposledni ra radě patři dík početnému týmu pracovníků a spolupracovníkủ bývalé Zemědělské vodohospodářské správy, kteři nashromáždili a zpracovali velké množství údajů o drobných vodních tocích České republiky. Článek vznikl s podporou Technologické agentury ČR, v rámci projektu č. TA02020395.

\section{Literatura}

[1] Lake, S.P. Drought and aquatic ecosystems. Effects and responses. Chichester, UK: Wiley-Blackwell, 2011, 381 p. [2] Brázdil, R., M. Trnka, L. Řezníčková, J. Balek, L. Bartošováaj. Suchov českýchzemích:minulost, současnost a budoucnost. Brno: Centrum výzkumu globální změny, Akademie věd České republiky, v. v. i., 2015, 402 s. Historie počasí a podnebí v českých zemích, svazek XI. ISBN 978-80-87902-11-0.

[3] Treml, P. Nejvýznamnější období sucha v letech 1956-2009 na území České republiky. VTEl, roč. 52, mimoř. č. II., 2010, s. 13-16.

[4] Treml, P. Největší sucha na území České republiky v období let 1875-2010. Meteorologické zprávy, 64, 2011, s. $168-176$

[5] Treml, P. Největší hydrologická sucha 20. století. In: Workshop Adolfa Patery 2012 - Extrémní hydrologické jevy v povodích (Smelík, L. a J. Jandora, eds), 2012, s. 251-258.

[6] Treml, P. Rok 2014 v kontextu největších such let 1804-2010, aneb bude nejsušší? In: Hydrologie malého povodí (sborník z konference Hydrologie malého povodí), 2014, s. 539-543.

[7] Řičicová, P., J. Daňhelka, H. Návojová a H. Kourková. Sucho v českých povodích v roce 2003. Vodni hospodárství. č. 2, 2004, s. 25-29.

[8] Daňhelka J., M. Boháč, I. Crhová, R. Čekal, I. Černá aj. Vyhodnocení sucha na území České republiky v roce 2015. Předběžná zpráva, Český hydrometeorologický ústav, 2015, 73 s.

[9] Anonym. Príprava realizace opatření pro zmírnění negativních dopadů sucha a nedostatku vody. 2015. Dostupné z: http://eagri.cz/public/web/file/417667/_3_material_VLADA.pdf.

[10] Dai, A. Drought under global warming: a review. Wiley Interdisciplinary Reviews: Climate Change2, 2011, p. 45-65. [11] Blauhut, V., I. Gudmundsson, and K. Stahl. Towards pan-European drought risk maps: quantifying the link between drought indices and reported drought impacts. Environmental Research Letters, 10, 2015, p. 1-10.

[12] Tolasz, R., R. Brázdil, O. Buliřr, P. Dobrovolný, M. Dubrovský, L. Hájková aj. Atlas podnebí Česka. Praha, Olomouc: Český hydrometeorologický ústav, Universita Palackého, 2007, 256 s.

[13] Beran, A. a M. Hanel. Definovaní zranitelných oblastí z hlediska nedostatku vody na území České republiky. VTEl 4-5, 2015, p. 23-26.

[14] Zelinka, M. The effect of low discharge rates on mayfly fauna. p. 282-286. In: Landa V.. Soldán T. \& Tonner M. (eds), Proc. IVth Int. Conf. Ephemeroptera, Bechyně. České Budějovice: Czechoslovak Academy of Sciences, 1984, 345 p.

[15] Směrnice 2000/60/ES Evropského parlamentu a Rady z 23. ŕína 2000 ustavující rámec pro činnost Společenství v oblasti vodní politiky. Aktualizovaný pracovní překlad s anglickým originálem. Praha, MŽP, Odbor ochrany vod, 2005 .

[16] Mrkvičková, M. a P. Balvín. Návrh postupu stanovení minimálního zůstatkového průtoku. VTEl, roč. 55, č. 3, 2013, p. 12-16, príloha Vodního hospodáŕství č. 6/2013.

[17] Strahler, A.N. Quantitative analysis of watershed geomorphology. American Geophysical Union Transactions 38, 1957, p. 913-920

[18] VInas, R., O. Novický, L. Kašpárek, E. Hanslík. aj. Časová a plošná variabilita hydrologického sucha v podminkách klimatické změny na územi České republiky. Praha: Výzkumný ústav vodohospodářský T.G. Masaryka,v.v.i., Praha, 2010, 160 s.

[19] Ondráček, P. Vyhodnocení trendů kvysychavosti vodních tokü: Projekt TA ČR BIOSUCHO a databáze SALAMANDER - Hydrogeologické hodnocení povodí. Zpráva. Brno, 2014, $16 \mathrm{~s}$.

[20] Podhrázská, J. a F. Toman. Vliv hospodaření v povodí na změny odtokových poměrů. In: Rožnovský, J. a T. Litschmann (eds) XIV. Česko-slovenská bioklimatologickákonference, Lednice na Moravě2.-4. záŕí2002, s. 352-356.

[21] Pařil, P., V. Syrovátka, M. Straka, M. Polášek, S. Zahrádková aj. Metodika retrospektivní bioindikace epizod vyschnutí toku na základě analýzy složení makrozoobentosu. Metodika připravovaná pro certifikaci (MŽP 2015).

[22] ČSN 757701. Jakost vod - Metodika odběru a zpracování vzorků makrozoobentosu tekoucích vod metodou PERLA. Praha: Český normalizační institut, 2008, 16 s.

[23] ČSN 757716. Jakost vod - Biologický rozbor - Stanovení saprobního indexu. Praha: Český normalizační institut, 1998, 174 s.

[24] Kokeš, J., S. Zahrádková, D. Němejcová aj. The PERLA system in the Czech Republic: A multivariate approach to assess ecological status of running waters. Hydrobiologia, 566, 2006, p. 343-354.

[25] Pretel, J.,L. Metelka, J. Kalvová., O. Novický, L. Kašpárek aj. Zpřesnění dosavadních odhadů dopadů klimatické změny v sektorech vodního hospodářství, zemědělství a lesnictví a návrhy adaptačních opatření (II) - Závěrečná zpráva o řešení projektu v roce 2010. Praha: ČHMÚ, 2010, 89 s.

[26] Štěpánek, P. P. Zahradníček, and R. Huth. Interpolation techniques used for data quality control and calculation of technical series: an example of a Central European daily time series. Quarterly Journal of Hungarian Meteorological Service, 115, n. 1-2, 2011, p. 87-98.

[27] Beran, A., S. Horáček a M. Hanel. Zjednodušení metody výpočtu evapotranspirace v nové verzi modelu Bilan, VTEI, 53, mimoř. č. I., 2011, s. 17-20, př́loha Vodního hospodárství č. 5/2011.

[28] Demek, J. a P. Mackovčin. (eds) Zeměpisný lexikon ČR. Hory a nižiny. Brno: Agentura ochrany prírody a krajiny ČR. 2006, 582 s. ISBN 80-86064-99-9.

[29] Balák, I. JESO. Jednotná evidence speleologických objektů. Speleo, 55, 2010, s. 7-13.

[30] DIBAVOD (Digitální báze vodohospodářských dat) [online]. @ Výzkumný ústav vodohospodářský T. G. Masaryka, v.v.i., Odbor ochrany vod a informatiky, odd. GIS, 2007 [citováno 18. 10. 2010]. Dostupnéz: 
<http:// www.dibavod.cz>. Referenční geografická databáze pro tvorbu tematických kartografických výstupů s vodohospodárskou tematikou a tematikou ochrany vod.

[31] ČSN 752410. Malé vodní nádrže. Praha: Úřad pro technickou normalizaci, metrologii a státní zkušebnictví, 2011, $46 \mathrm{~s}$.

[32] STATSOFT, Inc. STATISTICA for Windows [SoftwareSystem for Dateanalyses] Version 12, 2013. www.statsoft.com

[33] Rosenberg, D.M. and V.H. Resh. (eds) Freshwater Biomonitoring and Benthic Macroinvertebrates. New York: Chapman and Hall, 1993, $488 \mathrm{~s}$.

[34] Pařil, P., V. Syrovátka, M. Straka, M. Polášek aj. Odborná zpráva o postupu prací a dosažených výsledcích v rámci projektu Vysychání toků v období klimatické změny: predikce rizika a biologická indikace epizod vyschnutí jako nové metody pro management vodního hospodářství a údržby krajiny (TA02020395) za rok 2014. Brno: Výzkumný ústav vodohospodárský T.G. Masaryka, v. v. i., 2015, 44 s.

[35] Bojková, J., T. Soldán, S. Zahrádková, P. Chvojka, and M. Trýzna. Ephemeroptera and Plecoptera of the Bohemian Switzerland National Park, Czech Republic: species diversity and taxocenoses of sandstone watercourses. Lauterbornia, 70, 2010, p. 91-110

[36] Křivánek, J., J. Němec a J. Kopp. Rybníky v České republice. Praha: Consult, 2012, s. 303.

[37] Beran, A. a A. Vizina. Odvození regresních vztahů pro výpočet výparu z volné hladiny a identifikace trendů ve vývoji měřených veličin ve výparoměrné stanici Hlasivo. VTEl, 55, č. 4, 2013, s. 4-8, príloha Vodniho hospodárství č. 8/2013.

[38] Martinéz, A., A. Larranaga, A. Bassaguren, J. Pérez, C. Mendoza-Lera, and J. Pozo. Stream regulation by small dams affects benthic macroinvertebrate communities: from structural changes to functional implications. Hydrobiologia, 711, 2013, p. 31-41.

[39] Habets, F., E. Philippe, E. Martin, C.H.David, and F. Leseur. Small farm dams: impact on river flows and sustainability in a context of climate change. Hydrol. Earth Syst. Sci., n. 18, 2014, p. 4207-4222.

[40] Just, T., V. Šámal, M. Dušek, D. Fischer, P. Karlíka J. Pykal. Revitalizace vodního prostředí. Praha: AOPK, 2003, 144 s.

\section{Autoři}

doc. RNDr. Světlana Zahrádková, Ph.D.,

凶svetlana_zahradkova@vuv.cz

Mgr. Ondřej Hájek ${ }^{2}$

凶ohajek@sci.muni.cz

Mgr. Pavel Treml ${ }^{1}$

凶pavel_treml@vuv.cz

RNDr. Petr Pařil, Ph.D. ${ }^{1,2}$

凶petr_paril@vuv.cz

Mgr. Michal Straka, Ph.D. ${ }^{3}$

凶straka@wellcon.cz

RNDr. Denisa Němejcová

凶denisa_nemejcova@vuv.cz

Mgr. Marek Polášek ${ }^{1,2}$

凶marek_polasek@vuv.cz

Mgr. Pavel Ondráček, Ph.D. ${ }^{4}$

凶ondracek@enviaqua.cz

${ }^{1}$ Výzkumný ústav vodohospodářský TGM, v.v.i., Praha a Brno

2 Ústav botaniky a zoologie, Masarykova univerzita

${ }^{3}$ WELL Consulting, s. r. o.

${ }^{4}$ ENVI-AQUA, s. r. o.

Příspěvek prošel lektorským řízením.

\section{RISK ASSESSMENT OF DRYING UP OF SMALL STREAMS IN THE CZECH REPUBLIC}

\section{ZAHRADKOVA, S. ${ }^{1,2}$; HAJEK, O. ${ }^{2}$; TREML, P. ${ }^{1}$; PARIL, P. 1,2; STRAKA, M. ${ }^{3}$; NEMEJCOVA, D.'; POLASEK, M. ${ }^{1,2}$; ONDRACEK, ${ }^{1}{ }^{4}$}

${ }^{1}$ TGM Water Research Institute, p. r. i., Prague and Brno

${ }^{2}$ Department of Botany and Zoology, Masaryk University

${ }^{3}$ WELL Consulting, Ltd.

${ }^{4}$ ENVI-AQUA, Ltd.

Key words: drought - map - stream - precipitation deficit - land cover benthic macroinvertebrate - bioindication - running water

A categorization of the Czech Republic territory in terms of the risk of drying up of small streams ( $1^{\text {st }}$ to $4^{\text {th }}$ order by Strahler) was proposed. Three levels of risk (low, medium and high) for basic hydrological units (catchment) were set. The risk levels were defined using selected abiotic characteristics of the hydrological units and their combinations. The selection of characteristics and their limit values were derived using a statistical method of classification trees. The set of sites divided into groups depending on whether they were found drying or not was evaluated. The drying up of streams was detected with the help of a new method of retrospective bioindication. This new method based on the analysis of benthic macroinvertebrates was developed within the comprehensive research of permanent and drying up streams between 2012 and 2015. Using that method 332 sites (1362 samples) located at small streams and monitored in the Czech Republic between 1997 and 2010 were evaluated. The degree of risk was derived from the following characteristics: the precipitation deficit, land cover type, the share of rocks containing clays, geomorphological characteristics and the share of standing waters in the catchment. According to our assessment the area of low risk of drying up of streams up to $4^{\text {th }}$ Strahler order represents $45.3 \%$ of the area of the Czech Republic, while the area of medium and high risk $23.3 \%$ and $31.3 \%$ respectively. Typical catchments with a high risk are those with a predominance of arable land and with the share of standing water bodies greater than $1 \%$. The proposed categorization is to serve as a basis for decision-making processes, particularly for the water resource management, agriculture and conservation. 